
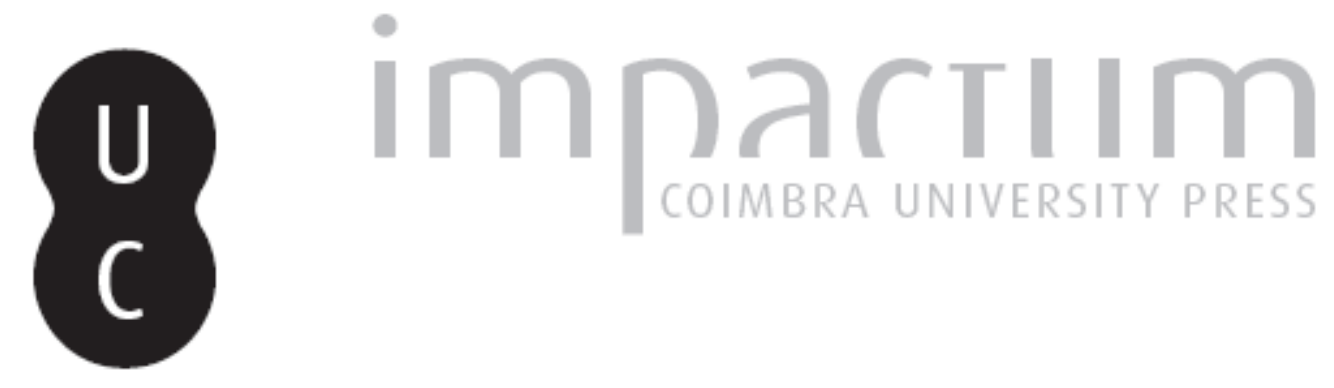

\title{
Nótulas sobre a reforma do sector bancário da União Europeia após a crise financeira de 2007
}

Autor(es): $\quad$ Quelhas, José Manuel

Publicado por: Faculdade de Direito da Universidade de Coimbra

URL persistente:

URI:http://hdl.handle.net/10316.2/35532

DOI:

DOI:http://dx.doi.org/10.14195/0870-4260_56_7

Accessed : $\quad$ 26-Apr-2023 06:24:29

A navegação consulta e descarregamento dos títulos inseridos nas Bibliotecas Digitais UC Digitalis, UC Pombalina e UC Impactum, pressupõem a aceitação plena e sem reservas dos Termos e Condições de Uso destas Bibliotecas Digitais, disponíveis em https://digitalis.uc.pt/pt-pt/termos.

Conforme exposto nos referidos Termos e Condições de Uso, o descarregamento de títulos de acesso restrito requer uma licença válida de autorização devendo o utilizador aceder ao(s) documento(s) a partir de um endereço de IP da instituição detentora da supramencionada licença.

Ao utilizador é apenas permitido o descarregamento para uso pessoal, pelo que o emprego do(s) título(s) descarregado(s) para outro fim, designadamente comercial, carece de autorização do respetivo autor ou editor da obra.

Na medida em que todas as obras da UC Digitalis se encontram protegidas pelo Código do Direito de Autor e Direitos Conexos e demais legislação aplicável, toda a cópia, parcial ou total, deste documento, nos casos em que é legalmente admitida, deverá conter ou fazer-se acompanhar por este aviso.

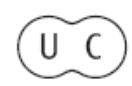




\section{UNIVERSIDADE DE COIMBRA}

FACULDADE DE DIREITO

\section{BOLETII DE CIÊECIAS ECONÓMICAS}

VOLUME LVI

$\begin{array}{llll}2 & 0 & 1 & 3\end{array}$

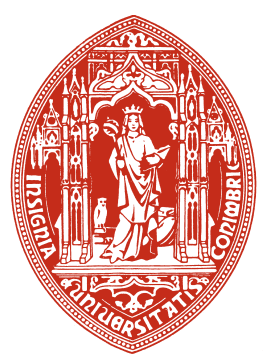

COIMBRA 


\section{NÓTULAS SOBRE A REFORMA DO SECTOR BANCÁRIO DA UNIÃO EUROPEIA APÓS A CRISE FINANCEIRA DE 2007}

\section{Nota prévia}

Em Fevereiro de 2012, o Comissário Europeu para o Mercado Interno e os Serviços, Michel Barnier, mandatou o Governador do Banco da Finlândia, Erkki Liikanen, para presidir ao "Grupo de especialistas de alto nível sobre a reforma estrutural do sector bancário da União Europeia». A carta de mandato ${ }^{1}$, publicada no site da Comissão Europeia, elegeu cinco objectivos primordiais de actuação: i) Redução do risco sistémico; ii) Redução do risco de contágio; iii) Redução do risco moral; iv) Promoção da concorrência; v) Manutenção da integridade do mercado interno.

Em 2 Outubro de 2012, foi publicado o Final Report do High-level Expert Group on reforming the structure of the EU banking sector ${ }^{2}$, cujo preâmbulo evidencia que a deflagração da crise financeira de 2007 foi antecedida pela tomada excessiva de riscos, através da utilização de instrumentos financeiros complexos, e pela preponderância do financiamento de curto prazo por parte das instituições de crédito. Ao mesmo

1 Cfr. Comissão Europeia (2012b, p. 1)

${ }^{2}$ Cfr. Liikanen, Bänziger, Campa, Gallois, Goyens, Krahnen, Mazzucchelli, Ser geant, Tuma, Vanhevel e Wijffels (2012). 
tempo, o referido preâmbulo revela a inadequação dos mecanismos de protecção dos depositantes e a interconexão estreita entre os bancos europeus.

Ab initio, o Relatório do "Grupo de especialistas» relaciona o exame dos factores geradores da crise financeira de 2007 com a eleição dos objectivos primordiais do seu mandato de actuação. Com efeito, a generalização de instrumentos financeiros complexos e o predomínio de operações de curto prazo aumentaram a exposição das instituições de crédito ao risco de volatilidade dos mercados financeiros, que não apenas o bancário. Destarte, a interconexão entre os mercados bancário, monetário, cambial e de capitais demonstra que as dificuldades de um banco rapidamente se disseminam pelos restantes e pelo sistema financeiro no seu todo, o que justifica a preocupação da Comissão Europeia com o risco de contágio e com o risco sistémico.

Acresce que a aludida inadequação dos mecanismos de protecção dos depositantes patenteia as debilidades da União Europeia relativas à supervisão, à regulação e ao resgate das instituições de crédito, o que suscita o debate em torno da arquitectura do sistema financeiro, mormente do sector bancário, bem como da prossecução dos objectivos de redução do risco moral, de promoção da concorrência e de integridade do mercado interno.

O debate sobre a arquitectura do sistema financeiro reabre a discussão entre os partidários dos princípios da especificidade e da especialização do sector bancário e os defensores do princípio da «banca universal», bem como a controvérsia acerca da reemergência dos princípios da (re)especificidade e da (re)especialização da actividade bancária.

Por sua vez, os objectivos de redução do risco moral, de promoção da concorrência e de integridade do mercado interno subjazem à polémica entre a primazia pelas operações de bailout ou pelas operações de bail-in das entidades bancárias. 


\section{Fundamentação do mandato da Comissão Euro- peia ao "Grupo de especialistas de alto nível sobre a reforma estrutural do sector bancário da União Europeia»}

\subsection{Redução do risco sistémico}

A crise do subprime, iniciada em 2007 nos Estados Unidos, disseminou-se rapidamente pelos vários sectores financeiros norte-americanos e propagou-se aceleradamente a diferentes continentes, afectando quer os mercados de capitais, monetários e cambiais, quer os mercados reais de múltiplos países.

Destarte, a discussão em torno da relevância científica e da pertinência prática do conceito de «risco sistémico» ${ }^{3}$ reganhou acuidade após 2007.

A relevância científica do conceito de "risco sistémico» era questionada sobretudo pelos cultores da visão monetarista - cfr. Schwartz (1995) e Bordo, Mizrach e Schwartz (1995) - que o classificavam de impreciso, de redundante e de supérfluo.

Na senda de Friedman e Schwartz (1993), Schwartz (1995, pp. 25-26) restringia as crises financeiras aos «pânicos bancários» ${ }^{4}$, que precipitavam as corridas aos levantamentos

3 Sobre a noção de «risco sistémico», cfr. QuelHas (2012c), sobretudo o "Capítulo 3. Do risco sistémico e do «efeito de contágio»: São as crises financeiras sistémicas?”. Acerca da polémica em torno da relevância do conceito de "risco sistémico", cfr. Quelhas (2012c), mormente em "3.1. O risco sistémico: um conceito em construção".

${ }^{4}$ Sobre a diferenciação entre os conceitos de "financial crisis" (crise financeira), "financial distress" (dificuldade financeira), "financial fragility" (fragilidade financeira) e "pseudo-financial crises" ("pseudocrises financeiras»), cfr. ScHWARTZ (1995, pp. 25-26).

Em sistemas de reservas fraccionadas, as «crises financeiras» caracterizam-se pela «fuga para a moeda», pela corrida aos depósitos, pela contracção múltipla das reservas bancárias e pela redução do stock de moeda, 
dos depósitos e as consequentes contracções drásticas das reservas do sistema bancário. Neste sentido, as crises financeiras resultariam da inabilidade das autoridades monetárias para travarem a «fuga para a moeda», bem como da actuação errónea das autoridades reguladoras, ou seja, a origem das crises financeiras seria exógena em relação à actividade económica real, a qual tenderia endogenamente para o equilíbrio ${ }^{5}$.

A pertinência prática do conceito de «risco sistémico» também era criticada pelos monetaristas, por força da natureza alarmista da expressão, que exacerbaria o pânico entre os depositantes e diminuiria a resiliência endógena do sistema financeiro ${ }^{6}$.

ao passo que «as pseudocrises financeiras» não representam a insuficiência de meios de pagamento, nem a competição por «high powered money».

${ }^{5}$ De forma elucidativa, Schwartz (1998, p. 251) resume a exogeneidade das crises financeiras nos seguintes termos: "creio que a instabilidade do sector financeiro é atribuível às acções desestabilizadoras das autoridades monetárias e dos reguladores; que o sector dos serviços financeiros não é inerentemente instável; que as dificuldades e as falências das sociedades financeiras, devidas à má gestão ou à má sorte, não são uma ameaça para o sistema como um todo; que os declínios nos preços dos títulos, das acções, do imobiliário ou das obras de arte indicam perdas de riqueza e não crises financeiras; que uma crise financeira genuína ocorre apenas quando o sistema de pagamentos está enfraquecido".

${ }^{6}$ A irrelevância prática do conceito de risco sistémico é enfatizada por SCHWARTZ (1998, p. 251), quando afirma: “As empresas financeiras não são mais imprudentes do que as empresas não financeiras. A má gestão e a fraude não são mais imperantes na finança do que na indústria em geral. A insolvência de bancos individuais não necessita de ter efeitos contagiosos sobre outras instituições solventes. Um prestamista de última instância eficiente pode evitar os pânicos. As autoridades monetárias que asseguram a estabilidade do nível de preços também alcançarão a estabilidade financeira. As únicas restrições sobre as instituições financeiras, necessárias como salvaguarda contra a tomada excessiva de risco, são as exigências de capital e o fecho de empresas antes que o seu valor líquido se torne negativo". 
Por um lado, a propagação do pânico diminuiria a capacidade dos depositantes discernirem a solvabilidade dos depositários, o que configuraria situações de «selecção adversa». Por outro lado, a percepção da diminuição da resiliência endógena do sistema financeiro justificaria a criação de redes públicas de salvamento, o que propiciaria condições de «risco moral» ${ }^{7}$.

Após 2007, a crise do subprime evidenciou a relevância científica e a pertinência prática do conceito de «risco sistémico» ${ }^{8}$. Com efeito, a amplitude da crise alertou para a fragilidade endógena do sistema financeiro, para a influência do comportamento de operadores dotados de racionalidade limitada e para o alcance da intervenção estabilizadora e reguladora dos mercados por parte de autoridades públicas.

Deste modo, afirmam-se as especificidades do mercado financeiro perante as restantes actividades económicas, mormente as decorrentes da propagação das consequências disruptivas sistémicas da falência de um operador, maxime de um banco, e da importância da estabilidade financeira para o curso normal da economia real ${ }^{9}$.

Em resposta à crise financeira de 2007, a União Europeia aprovou, em Novembro de 2010, um «pacote legislativo» ${ }^{10}$, em que se destaca a criação do Comité Euro-

7 Sobre a relação entre os conceitos de «risco sistémico», de «selecção adversa» e de «risco moral», cfr. QuelHAS (2012c), nomeadamente em "3.1.3. Visão intermédia: da disrupção dos fluxos de informação como fundamento do conceito de risco sistémico".

8 Sobre a admissão de um conceito amplo de "risco sistémico», cfr. Bartholomew e Whalen (1995) e Quelhas (2012c), sobretudo em "3.1.2. Visão ampla: da ambiguidade construtiva do conceito de risco sistémico".

9 Sobre a compreensão da estabilidade financeira como um «bem público», cfr. Feldstein (1991) e CROCKetT (2001).

10 Sobre o significado e o alcance do "pacote legislativo» de 24 de Novembro de 2010, cfr. QuelHas (2012b). 
peu do Risco Sistémico ${ }^{11}$, o que simboliza a institucionalização do próprio conceito.

\subsection{Redução do risco de contágio}

$\mathrm{O}$ risco de contágio encontra-se intrinsecamente associado ao risco sistémico a ponto de serem identificados, quer na "acepção de risco de reacção em cadeia" - cfr. KAUfMAn (1995), (2000a), (2000b), (2000c) e (2000d) -, quer na "acepção de risco de exposição a choques comuns" - cfr. Herring e Santomero (2000), Allen e Herring (2001) e FERNANDO e HERring (2001) ${ }^{12}$.

A primeira acepção exprime o "efeito dominó», ou seja, a probabilidade de quebras consecutivas ao longo de uma cadeia de operadores de mercado, geradoras de perdas cumulativas no sistema financeiro.

A segunda acepção realça as consequências disruptivas sistémicas decorrentes da exposição dos operadores de mercado a acontecimentos súbitos e imprevistos, endógenos ou

11 Cfr. Regulamento (UE) n. ${ }^{\circ} 1092 / 2010$ do Parlamento Europeu e do Conselho, de 24.11.2010, relativo à supervisão macroprudencial do sistema financeiro na União Europeia e que cria o Comité Europeu do Risco Sistémico, publicado no JO, L 331, de 15.12.2010, pp. 1-11. O art. $\left.^{\circ} 2 .^{\circ}, \mathrm{c}\right)$, deste Regulamento define «risco sistémico» nos seguintes termos: "um risco de perturbação do sistema financeiro susceptível de ter consequências negativas graves no mercado interno e na economia real. Todos os tipos de intermediários, de mercados e de infra-estruturas financeiros podem ser, em determinada medida, potencialmente importantes a nível sistémico".

12 Sobre as acepções que identificam o risco sistémico com o risco de contágio, cfr. QuelHAs (2012c), em “3.1.4. A identificação entre risco sistémico e risco de contágio directo, na acepção de risco de reacção em cadeia" e "3.1.5. A identificação entre risco sistémico e risco de contágio indirecto, na acepção de risco de exposição a choques comuns”. 
exógenos, cujas etiologias não se circunscrevem ao domínio financeiro.

Porém, o risco de contágio tem especificidades, que o diferenciam do risco sistémico. Com efeito, o risco de contágio exprime a probabilidade de transmissão de uma crise, enquanto o risco sistémico expressa a probabilidade dessa propagação afectar o sistema financeiro como um todo.

Aliás, a maioria da literatura económica não emprega a expressão «risco de contágio», mas sim «efeito de contágio» ${ }^{13}$ e centra a investigação no apuramento dos canais de transmissão ${ }^{14}$ e no exame das formas de propagação ${ }^{15}$.

Outra questão controvertida é a de saber se o contágio opera aleatoriamente ou de forma selectiva, isto é, se a disseminação das crises ocorre independentemente dos fundamentos reais e das relações económicas entre os países contagiantes e os contagiados ou em função desses fundamentos e dessas relações.

A afirmação da natureza aleatória da propagação das crises abre caminho à aceitação dos contributos do herd behaviour, da crowd psychology e das self-fulfilling prophecies ${ }^{16} \mathrm{e}$ tende a asseverar a imprescindibilidade das medidas de esta-

13 Sobre o "efeito de contágio», cfr. Quelhas (2012c), sobretudo em "3.2. «Efeito de contágio»: uma metáfora elucidativa ou um mito sem fundamento?".

14 Sobre os canais de transmissão, cfr. Quelhas (2012c), em “3.2.4 Dos canais de transmissão do «efeito de contágio»", onde se diferencia entre o «canal comercial» e o "canal financeiro».

15 Sobre as formas de propagação, cfr. QuelHas (2012c), sobretudo em "3.2.5. Das formas de propagação do "efeito de contágio»", onde, inter alia, se escalpeliza o papel das corridas bancárias, dos empréstimos interbancários, da rede de contratação financeira, do «risco moral», da informação assimétrica, da recomposição internacional das carteiras e das cadeias de crédito na disseminação das crises.

16 Sobre o relevo do "comportamento de grupo", da "psicologia da multidão» e das «profecias auto-sustentáveis» para a compreensão das crises 
bilização e de regulação dos mercados financeiros. Pelo contrário, a afirmação da natureza selectiva da propagação das crises rejeita os contributos do "comportamento de grupo", da "psicologia de multidão» e das "profecias auto-sustentáveis» e tende a prescindir das medidas de estabilização e de regulação.

Após 2007, a virulência e a amplitude da crise do subprime reforçaram o interesse pelos canais de transmissão e pelas formas de contágio, quer à escala internacional, quer na União Europeia.

$\mathrm{O}$ «considerando 7» do Regulamento (UE) n. ${ }^{\circ}$ 1092/2010 17 insere expressamente “os riscos de contágio no âmbito das crises financeiras" entre as motivações para a criação do Comité Europeu do Risco Sistémico.

Por sua vez, os artigos $25^{\circ}$, n. $^{\circ} 2$, e $27 .^{\circ}$, n. ${ }^{\circ} 1$, do Regulamento (UE) n. ${ }^{\circ}$ 1093/2010, que cria a Autoridade Bancária Europeia ${ }^{18}$, estabelecem que os planos e os métodos de resolução de instituições financeiras falidas devem ser definidos "em moldes que evitem o contágio".

No mesmo sentido, o art. $^{\circ} 25 .^{\circ}$, n. ${ }^{\circ} 2$, do Regulamento (UE) n. ${ }^{\circ} 1094 / 2010^{19}$, incumbe a Autoridade Europeia dos

financeiras, cfr. QuelHAs (2012c), sobretudo em "1.1.7.4. O papel do herd behaviour" e "3.3. Do carácter sistémico das crises financeiras".

17 Cfr. supra nota 11.

18 Cfr. Regulamento (UE) n. ${ }^{\circ} 1093 / 2010$ do Parlamento Europeu e do Conselho, de 24.11.2010, que cria uma Autoridade Europeia de Supervisão (Autoridade Bancária Europeia), altera a Decisão n. ${ }^{\circ}$ 716/2009/CE e revoga a Decisão 2009/78/CE da Comissão, publicado no JO, L 331, de 15.12.2010, pp. 12-47.

${ }_{19}$ Cfr. Regulamento (UE) n. ${ }^{\circ}$ 1094/2010 do Parlamento Europeu e do Conselho, de 24.11.2010, que cria uma Autoridade Europeia de Supervisão (Autoridade Europeia dos Seguros e Pensões Complementares de Reforma), altera a Decisão n. ${ }^{\circ}$ 716/2009/CE e revoga a Decisão 2009/79/CE da Comissão, publicado no JO, L 331, de 15.12.2010, pp. $48-83$. 
Seguros e Pensões Complementares de Reforma de "identificar as melhores práticas destinadas a facilitar a resolução de situações de falência das instituições e, em particular, grupos transfronteiriços, em moldes que evitem o contágio”.

Idêntica preocupação subjaz ao art. $^{\circ} 27 .^{\circ}$, n. $^{\circ} 1$, do Regulamento (UE) n. ${ }^{\circ}$ 1095/2010 ${ }^{20}$, que atribui à Autoridade Europeia dos Valores Mobiliários e dos Mercados competência "para o desenvolvimento de métodos para a resolução de falências de intervenientes-chave nos mercados financeiros por meios que evitem o contágio”.

De sublinhar que o Comité Europeu do Risco Sistémico e as três novas autoridades europeias de supervisão - Autoridade Bancária Europeia, Autoridade Europeia dos Seguros e Pensões Complementares de Reforma, Autoridade Europeia dos Valores Mobiliários e dos Mercados - elegem a evitação do contágio como forma de salvaguarda da estabilidade sistémica.

Em suma, à semelhança do conceito de «risco sistémico», os regulamentos constitutivos do "pacote legislativo» de Novembro de 2010 também institucionalizam, na União Europeia, o conceito de «risco de contágio».

\subsection{Redução do risco moral}

O conceito de «risco moral» associa-se aos conceitos de «risco sistémico» e de «risco de contágio», no âmbito da definição de políticas de resgate às instituições financeiras,

${ }^{20}$ Cfr. Regulamento (UE) n. ${ }^{\circ}$ 1095/2010 do Parlamento Europeu e do Conselho, de 24.11.2010, que cria uma Autoridade Europeia de Supervisão (Autoridade Europeia dos Valores Mobiliários e dos Mercados), altera a Decisão n. ${ }^{\circ}$ 716/2009/CE e revoga a Decisão 2009/77/CE da Comissão, publicado no JO, L 331, de 15.12.2010, pp. 84-119. 
maxime aos bancos ${ }^{21}$. Com efeito, a justificação das operações de resgate assenta na tentativa de bloqueio da propagação contagiosa das dificuldades financeiras entre diferentes instituições, de forma a impedir as consequências disruptivas sobre o sistema no seu todo.

Porém, a organização de redes públicas de salvamento pode induzir a assunção de comportamentos mais temerários por parte dos operadores, o que contraria o seu desígnio inicial. Nestes termos, suscita-se um trade-off entre o risco moral e o risco sistémico, ou seja, a admissibilidade de resgates diminui o risco sistémico, mas aumenta o risco moral, e a inadmissibilidade dos resgates aumenta o risco sistémico, mas diminui o risco moral.

A preocupação com o risco moral também está presente no projecto de reforma do sistema financeiro europeu, posterior à crise de 2007, mormente na Proposta de Directiva do Parlamento Europeu e do Conselho que estabelece um enquadramento para a recuperação e resolução de instituições de crédito e empresas de investimento, de 6 de Junho de 2012, quando refere:

"A fim de evitar o risco moral, qualquer instituição insolvente deve estar em condições de se retirar do mercado, independentemente da sua dimensão e do seu grau de interligação, sem provocar perturbações sistémicas. As instituições em dificuldades serão em princípio liquidadas ao abrigo dos procedimentos normais de insolvência. No entanto, a liquidação ao abrigo dos procedimentos normais de insolvência poderá pôr em causa a estabilidade financeira, interromper a prestação de serviços essenciais e afectar a protecção dos depositantes. Nesse caso, será do interesse público aplicar os

21 Sobre as relações entre o risco sistémico, o risco de contágio e o risco moral, cfr. QuelHAS (2012c), principalmente em "3.2.3.5. O «efeito de contágio» e o trade-off entre o «risco moral» e o risco sistémico”, e Quelhas (2012a, nota 31). 
instrumentos de resolução. Os objectivos da resolução deverão, por conseguinte, passar por garantir a continuidade dos serviços financeiros essenciais, manter a estabilidade do sistema financeiro, reduzir o risco moral minimizando o recurso a apoios financeiros públicos para as instituições em dificuldades e proteger os depositantes" [cfr. Comissão EuropeIA (2012c, p. 30, «considerando 27»)].

Este excerto sintetiza os elementos essenciais para a compreensão do risco moral, a saber: a) A insolvência de qualquer instituição financeira pode gerar efeitos disruptivos sistémicos, independentemente da sua dimensão e do seu grau de interligação; b) Os procedimentos normais de insolvência podem pôr em causa a estabilidade financeira, podem interromper a prestação de serviços essenciais e podem afectar a protecção dos depositantes; c) A defesa do interesse público requer a introdução de procedimentos especiais, mormente de instrumentos de resolução; d) A aplicação de instrumentos de resolução às instituições financeiras intenta alcançar quatro objectivos: $i$ ) a continuidade dos serviços financeiros essenciais; ii) a manutenção da estabilidade sistémica; iii) a redução do risco moral; iv) a protecção dos depositantes; e) A redução do risco moral enseja minimizar o recurso a apoios financeiros públicos.

De notar a contraposição entre os procedimentos normais e os procedimentos especiais, identificados com os instrumentos de resolução, cujo estabelecimento se funda na defesa do interesse público. Acresce que a invocação do interesse público não se cinge aos princípios da continuidade dos serviços, da estabilidade sistémica e da protecção dos depositantes, mas firma-se também no argumento de contenção da despesa pública em operações de resgate.

Destarte o trade-off entre o risco moral e o risco sistémico configura uma dimensão incontornável de finanças públicas, a saber: a realização de operações de resgate diminui 
o risco sistémico, mas aumenta o risco moral e acelera a despesa pública; a irrealização de operações de resgate aumenta o risco sistémico, mas diminui o risco moral e freia a despesa pública.

Neste cenário, as autoridades defrontam um dilema entre a estabilidade dos mercados financeiros e a estabilidade das finanças públicas: ou privilegiam a estabilidade dos mercados financeiros e organizam bailouts - o que agrava os défices orçamentais e aumenta a dívida pública -, ao mesmo tempo que induzem o risco moral, ou privilegiam a estabilidade das finanças públicas e não organizam bailouts - não agravando os défices orçamentais, nem aumentando a dívida pública -, ao mesmo tempo que retraem o risco moral.

Este dilema teria uma configuração diferente se a internalização dos custos com a estabilização dos mercados não agravasse o défice orçamental, nem aumentasse o endividamento público, o que relança o debate em torno das fontes de financiamento dos resgates, mormente sobre a pertinência da tributação das operações financeiras ${ }^{22}$.

\subsection{Promoção da concorrência}

As operações de bailout introduzem distorções à concorrência entre as instituições financeiras, sobretudo entre as que operam em mercados integrados de capitais e serviços, como é o caso da União Europeia.

De forma elucidativa, a Proposta de Directiva do Parlamento Europeu e do Conselho que estabelece um enquadramento para a recuperação e resolução de instituições de crédito e empresas de investimento, de 6 de Junho de 2012, sustenta:

22 Sobre a internalização fiscal dos custos das operações de resgate, cfr. Quelhas (2012b, pp. 889-892), Quelhas (2012a, pp. 263-278) e QuelHas (2013,pp. 858-863). 
“Alguns Estados-Membros já aprovaram alterações legislativas que introduzem mecanismos de resolução de instituições de crédito em dificuldades; enquanto outros manifestaram a intenção de o fazer se não forem adoptados a nível da União mecanismos desse tipo. As diferenças nacionais nas condições, poderes e processos para a resolução das instituições de crédito poderão constituir obstáculos ao funcionamento eficaz do mercado interno e prejudicar a cooperação entre as autoridades nacionais, quando confrontadas com o colapso de grupos bancários transfronteiriços. Isto é particularmente verdade quando a existência de abordagens diferentes significa que as autoridades nacionais não têm o mesmo nível de controlo ou os mesmos poderes para a resolução das instituições de crédito. Estas diferenças nos regimes de resolução podem afectar também os custos do financiamento bancário de forma diferente entre os Estados-Membros e resultar em distorções da concorrência entre os bancos. A existência de regimes de resolução eficazes em todos os Estados-Membros é também necessária para garantir que o exercício pelas instituições do direito de estabelecimento no âmbito do mercado único não seja limitado pela capacidade financeira do respectivo Estado-Membro de origem para gerir o seu eventual colapso" [cfr. Comissão Europeia (2012c, p. 24 , «considerando $5 »)]$.

Este trecho aduz cinco argumentos fundamentais em defesa do estabelecimento de um mecanismo comum de resolução de instituições de crédito à escala da União Europeia, designadamente: $i$ ) a heterogeneidade de regimes de resolução obsta ao funcionamento eficaz do mercado interno; ii) a heterogeneidade de regimes de resolução prejudica a cooperação entre as autoridades nacionais; iii) a heterogeneidade de regimes de resolução afecta os custos do financiamento bancário; iv) a heterogeneidade de regimes de resolução distorce 
a concorrência entre os bancos; $v$ ) a heterogeneidade de regimes de resolução limita o exercício do direito de estabelecimento no âmbito do mercado único.

Num ponto intitulado "promoção da concorrência», os argumentos indicados em iii) e em $v$ ) assumem particular relevância; com efeito, as diferenças dos custos do financiamento bancário repercutem-se sobre os accionistas e sobre os clientes e condicionam as opções de investimento dos primeiros e de realização de operações passivas e activas dos segundos; na ausência de um regime único de resolução, a eleição do estado-membro de estabelecimento pode ser condicionada pela percepção, que cada instituição de crédito tenha, sobre a capacidade de cada governo suportar o respectivo mecanismo nacional de resolução.

No mesmo sentido, o "considerando 72» da Proposta de Directiva, de 6 de Junho de 2012, acrescenta:

"A garantia de uma resolução efectiva das instituições financeiras em risco de colapso na União constitui um elemento fundamental para a realização do mercado interno. $\mathrm{O}$ colapso de uma instituição desse tipo afectará a estabilidade financeira não só nos mercados em que opera directamente como também no mercado financeiro da União no seu todo. A interligação dos diferentes sistemas financeiros nacionais foi reforçada com a conclusão do mercado interno dos serviços financeiros. As instituições operam fora do Estado-Membro em que estão estabelecidas e estão interligadas através do mercado interbancário e de outros mercados essencialmente pan-europeus. A garantia de um financiamento efectivo da resolução dessas instituições em condições de igualdade em todos os Estados-Membros é do interesse dos Estados-Membros em que operam mas também de todos os Estados-Membros em geral, como forma de assegurar a igualdade das condições de concorrência e de melhorar o funcionamento do mercado único da União no sector finan- 
ceiro. A criação de um sistema europeu de mecanismos de financiamento deverá assegurar que todas as instituições que operam na União sejam objecto de mecanismos de financiamento da resolução igualmente eficazes, contribuindo assim para a estabilidade do mercado único" [COMIssão Europeia (2012c, p. 40, «considerando 72»)].

Este excerto interliga claramente a criação de um mecanismo comum de resolução de instituições de crédito com a protecção dos mercados financeiros europeus contra o risco sistémico e contra o risco de contágio, reconhecendo que as externalidades negativas do colapso de um banco não se confinam às fronteiras de um estado-membro e que a preservação da estabilidade transfronteiriça é mais bem alcançada ao nível da União do que ao nível nacional, o que preenche os requisitos do princípio da subsidiariedade.

Sublinhe-se que a concretização plena do mercado interno de serviços financeiros não requer apenas a consagração dos princípios da livre circulação de capitais, do reconhecimento mútuo e do passaporte comunitário, mas exige também a igualdade de concorrência entre os operadores, independentemente do estado-membro em que operem ou do estado-membro de origem.

Em Julho de 2013, a importância da promoção da concorrência foi reafirmada na "exposição dos motivos» da Proposta de Regulamento do Parlamento Europeu e do Conselho que estabelece regras e um procedimento uniformes para a resolução de instituições de crédito e de certas empresas de investimento no quadro de um mecanismo único de resolução e de um fundo único de resolução bancária, nos seguintes termos:

“... a união bancária abrangerá todos os Estados-Membros pertencentes à área do euro e os Estados-Membros não pertencentes que optem por aderir. Será aplicado no âmbito da união bancária e em todos os outros Estados-Membros o 
mesmo conjunto único de requisitos prudenciais e as mesmas regras sobre a resolução dos bancos a nível da UE. Deste modo, será preservada a integridade do mercado interno. A estabilidade financeira reforçada gerada pela união bancária impulsionará igualmente a confiança e as perspectivas de crescimento em todo o mercado interno. Uma aplicação centralizada e uniforme das regras prudenciais e das regras de resolução nos Estados-Membros que participam na união bancária beneficiará todos os Estados-Membros. Ultrapassar a fragmentação financeira que actualmente entrava a actividade económica, contribuirá para garantir uma concorrência equitativa e para suprimir os obstáculos ao livre exercício das liberdades fundamentais não apenas nos Estados-Membros participantes, mas em todo o mercado interno" [COMISSÃo Europeia (2013, p. 3)].

Reafirma-se expressamente que a integridade do mercado interno pressupõe a aplicação do mesmo conjunto único de requisitos prudenciais e das mesmas regras sobre a resolução dos bancos. Deste modo, os objectivos da promoção da concorrência e da prossecução da estabilidade sistémica subjazem à criação da união bancária, além de contribuírem para a recuperação da confiança dos operadores e para a superação da crise do subprime.

Em suma, a promoção da concorrência nos mercados financeiros surge a par das preocupações com o risco sistémico, com o risco de contágio e com o risco moral, tanto no «pacote legislativo de Novembro de 2010», como nos textos preparatórios da institucionalização da união bancária.

\subsection{Manutenção da integridade do mercado interno}

Paradoxalmente, a controvérsia em torno da manutenção da integridade do mercado interno surge após a insti- 
tucionalização da 3. ${ }^{a}$ fase da União Económica e Monetária $(\mathrm{UEM})^{23}$. Seria expectável que a introdução do euro e a condução de políticas monetárias e cambiais únicas contribuíssem para a consolidação do mercado interno e não para a sua fragmentação. Porém, o impacto da crise do subprime na Europa fez emergir a fragilidade genesíaca da $\mathrm{UEM}^{24}$.

Com efeito, a resposta da União Europeia à crise de 2007 evidenciou a rigidez institucional, consagrada no próprio Tratado sobre o Funcionamento da União Europeia (TFUE), bem como a ausência de mecanismos comuns de resposta.

De forma inequívoca, o art. ${ }^{\circ} 127 .^{\circ}$ do TFUE subalterniza a estabilidade do sistema financeiro à estabilidade dos preços $^{25}$. Enquanto o n. 1 do art. $^{\circ} 127 .^{\circ}$ determina que "O objectivo primordial do Sistema Europeu de Bancos Centrais [...] é a estabilidade dos preços", o n. ${ }^{\circ} 5$ do mesmo artigo menciona que "O SEBC contribuirá para a boa condução das políticas desenvolvidas pelas autoridades competentes no que se refere à supervisão prudencial das instituições de crédito e à estabilidade do sistema financeiro".

A imperatividade do n. ${ }^{\circ} 1$ contrasta flagrantemente com a permissividade do $n .^{\circ} 5$, reiterada pelo n. ${ }^{\circ} 6$ do mesmo artigo, ao estabelecer que "O Conselho, por meio de regulamentos adoptados de acordo com um processo legislativo especial, por unanimidade, e após consulta ao Parlamento Europeu e ao Banco Central Europeu, pode conferir a este

${ }^{23}$ Sobre a relação entre a integração dos mercados financeiros dos estados-membros da União Europeia e a concretização das sucessivas fases da União Económica e Monetária, cfr. Quelhas (2012a, pp. 243-244).

${ }^{24}$ Sobre a fragilidade genesíaca da União Económica e Monetária, cfr. Quelhas (2012a, pp. 237-242), sobretudo em “1. O reforço da resiliência do sistema financeiro".

25 Sobre a hierarquia de objectivos consagrada no art. $^{\circ} 127 .^{\circ}$ do TFUE, cfr. GOMEs (2012, pp. 582-585). 
último atribuições específicas no que diz respeito às políticas relativas à supervisão prudencial das instituições de crédito e outras instituições financeiras, com excepção das empresas de seguros".

Acresce que o $\mathbb{S} 1$, do n. ${ }^{\circ} 2$, do art. ${ }^{\circ} 127 .{ }^{\circ}$ do TFUE insere a "definição e execução da política monetária da União" no elenco das "atribuições fundamentais cometidas ao SEBC", ao passo que o n. ${ }^{\circ} 5$ remete a "supervisão prudencial das instituições de crédito" e a "estabilidade do sistema financeiro" para as "autoridades competentes".

Destarte, o próprio TFUE traça uma dicotomia entre as funções de condução da política monetária pelo SEBC e as funções de estabilização do sistema financeiro pelas autoridades competentes dos estados-membros ${ }^{26}$, a qual dificulta a concertação de respostas europeias comuns à crise do subprime.

26 Esta dicotomia é reafirmada no Protocolo relativo aos Estatutos do Sistema Europeu de Bancos Centrais e do Banco Central Europeu, anexo ao Tratado da União Europeia (TUE) e ao TFUE. Com efeito, o art. ${ }^{\circ}$ 25. ${ }^{\circ}$, n. ${ }^{\circ}$ 1, do Protocolo estabelece que "O BCE pode dar parecer e ser consultado pelo Conselho, pela Comissão e pelas autoridades competentes dos Estados-membros sobre o âmbito e a aplicação da legislação da União relativa à supervisão prudencial das instituições de crédito e à estabilidade do sistema financeiro", o que secundariza o papel do BCE nestas matérias.

É verdade que o n. ${ }^{\circ} 2$ do art. $^{\circ} 25 .^{\circ}$ do Protocolo alarga o âmbito do n. ${ }^{\circ} 1$, ao admitir que "De acordo com um regulamento do Conselho adoptado nos termos do n. ${ }^{\circ} 6$ do artigo $127 .{ }^{\circ}$ do Tratado sobre o Funcionamento da União Europeia, o BCE pode exercer atribuições específicas no que diz respeito às políticas relativas à supervisão prudencial das instituições de crédito e de outras instituições financeiras, com excepção das empresas de seguros"; contudo, esta extensão de competências reitera os requisitos do art. ${ }^{\circ} 127 .^{\circ}$, n. $^{\circ} 6$, do TFUE, nomeadamente o da adopção prévia, por unanimidade, de um regulamento do Conselho, de acordo com um processo legislativo especial. 
A aludida fragilidade genesíaca da UEM consubstancia o risco de fragmentação dos mercados financeiros europeus, o que pode perigar a integridade do próprio mercado interno. Aliás, vários dos documentos preparatórios da união bancária alertam expressamente para esta possibilidade ${ }^{27}$.

Fazendo uso da prerrogativa do art. ${ }^{\circ} 127 .^{\circ}$, n. $^{\circ}$ 6, do TFUE, o Regulamento (UE) n. ${ }^{\circ}$ 1096/2010 do Conselho confere ao BCE atribuições específicas no que se refere ao funcionamento do Comité Europeu do Risco Sistémico ${ }^{28}$. Contudo, as atribuições específicas conferidas ao BCE restringem-se ao "apoio analítico, estatístico, administrativo e logístico" ao Comité Europeu do Risco Sistémico, como expressamente refere o «considerando 9» do Regulamento (UE) n. ${ }^{\circ}$ 1096/2010:

“... o Conselho concluiu que o BCE deverá prestar apoio analítico, estatístico, administrativo e logístico ao ESRB. Cabendo ao ESRB debruçar-se sobre todos os aspectos e domínios da estabilidade financeira, o BCE deverá associar os bancos centrais e as entidades supervisoras nacionais para que disponibilizem os seus conhecimentos específicos. A opção de conferir ao BCE atribuições específicas no que diz respeito às políticas relativas à supervisão prudencial, prevista no Tratado sobre o Funcionamento da União Europeia, deverá, por conseguinte, ser exercida, através da atribuição ao BCE da tarefa de assegurar o secretariado do ESRB".

27 Sobre o relevo da união bancária para a manutenção da integridade do mercado interno, cfr. QuelHAS (2012a, pp. 283-286), mormente o ponto "6. Em jeito de síntese: o impedimento da fragmentação dos mercados financeiros".

28 Cfr. Regulamento (UE) n. ${ }^{\circ}$ 1096/2010 do Conselho, de 17.11.2010, que confere ao Banco Central Europeu atribuições específicas no que se refere ao funcionamento do Comité Europeu do Risco Sistémico, publicado no JO, L 331, de 15.12.2010, pp. 162-164. 
$\mathrm{Na}$ verdade, a influência do BCE extravasa a que decorre da simples assessoria técnica porque, nos termos do art. ${ }^{\circ}$ 1. ${ }^{\circ}$ do Regulamento (UE) n. ${ }^{\circ}$ 1096/2010, o Presidente e o Vice-Presidente do BCE são membros do Conselho Geral do Comité Europeu do Risco Sistémico ${ }^{29}$. Todavia, a opção subjacente ao "pacote legislativo» de Novembro de 2010 foi a de outorgar todos os aspectos e domínios da estabilidade financeira ao Comité Europeu do Risco Sistémico, criado pelo Regulamento (UE) n. ${ }^{\circ}$ 1092/2010.

A prerrogativa do art. ${ }^{\circ} 127 . .^{\circ},{ }^{\circ} .^{\circ} 6$, do TFUE, também é invocada pelo Regulamento (UE) n. ${ }^{\circ}$ 1024/2013, que confere ao BCE atribuições específicas no que diz respeito às políticas relativas à supervisão prudencial das instituições de crédito ${ }^{30}$. Sublinhe-

${ }^{29}$ Por força do artigo 6. ${ }^{\circ}$ do Regulamento (UE) n..$^{\circ}$ 1092/2010, no Conselho Geral do Comité Europeu de Risco Sistémico coexistem membros com direito de voto e membros sem direito de voto. De acordo com o n. ${ }^{\circ} 1$ do mesmo artigo, são membros com direito de voto: o Presidente e o Vice-Presidente do BCE; os Governadores dos bancos centrais nacionais; um membro da Comissão Europeia; o Presidente da Autoridade Bancária Europeia; o Presidente da Autoridade Europeia dos Seguros e Pensões Complementares de Reforma; o Presidente da Autoridade Europeia dos Valores Mobiliários e dos Mercados; o Presidente e os dois Vice-Presidentes do Comité Científico Consultivo; o Presidente do Comité Técnico Consultivo. Por seu turno, o n. ${ }^{\circ} 2$ do art. $^{\circ} 6 .^{\circ}$ define como membros sem direito de voto: um representante de alto nível das autoridades nacionais de supervisão competentes de cada Estado-Membro, que pode ser revezado em função da matéria em debate; o Presidente do Comité Económico e Financeiro.

Sublinhe-se que o Presidente e o Vice-Presidente do BCE são membros com direito de voto do Conselho Geral e que o art. ${ }^{\circ}{ }^{\circ} .^{\circ}$, n. ${ }^{\circ} 2$, do Regulamento (UE) n. ${ }^{\circ}$ 1092/2010, atribuiu a presidência do Comité Europeu do Risco Sistémico ao Presidente do BCE, nos primeiros cinco anos após a sua entrada em vigor.

30 Cfr. Regulamento (UE) n. ${ }^{\circ}$ 1024/2013 do Conselho, de 15.10.2013, que confere ao BCE atribuições específicas no que diz respeito às políticas relativas à supervisão prudencial das instituições de crédito, publicado no JO L 287, de 29.10.2013, pp. 63-89. 
-se que estas atribuições específicas prosseguem os objectivos de superação da fragilidade genesíaca da UEM e de preservação da integridade do mercado interno.

Neste sentido, o «considerando 2» do Regulamento (UE) n. ${ }^{\circ}$ 1024/2013 sustenta:

"A actual crise financeira e económica veio demonstrar que a fragmentação do sector financeiro pode ameaçar a integridade da moeda única e do mercado interno. É, pois, essencial intensificar a integração da supervisão bancária, a fim de reforçar a União, restaurar a estabilidade financeira e lançar as bases da recuperação económica".

De notar que a fragmentação do sector financeiro representa uma dupla ameaça: pode frustrar a integridade da moeda única; pode perigar a integridade do mercado interno.

A quebra da integridade da moeda única representaria um revés significativo no objectivo gizado no art. $^{\circ} 3 .^{\circ}$, n. ${ }^{\circ} 4$, do TUE $^{31}$, bem como no art. ${ }^{\circ} 119 .^{\circ}$, n. $^{\circ} 2$, do TFUE ${ }^{32}$.

$31 \mathrm{O}$ art. $^{\circ} 3 .^{\circ}$, n. $^{\circ}$ 4, do TUE determina que "A União estabelece uma união económica e monetária cuja moeda é o euro", ou seja, a criação da UEM constitui um dos objectivos ou uma das atribuições da União Europeia.

Nas palavras de Sousa (2012, p. 32), "Como ficou anotado a propósito do art $2 .^{\circ}$, os objectivos da União projectam os seus valores e são desenvolvidos pelo TUE e pelo TFUE, através de políticas concretizadoras. São, pois, transversais, por se reflectirem em todas as disposições dos Tratados relativas às matérias que cobrem, e dotados de operacionalidade intermédia, maior do que a dos valores, menor do que a das concretizações área a área. Na respectiva operacionalidade cabe o servirem de padrão de aferição do grau de respeito do modelo político, económico e social europeu por parte das condutas destinadas a prosseguirem os fins enunciados. Se o traçado dos valores define a identidade axiológica da Europa e da União, o elenco dos objectivos delineia o modelo de densificação daquela identidade num determinado período histórico. A violação dos valores questiona a pertença integral ou efectiva à União. 


\section{A quebra da integridade do mercado interno constituiria um retrocesso histórico num dos pilares da União Europeia,}

O desvio dos fins revela o afastamento, explícito ou implícito, do modelo da União consensualizado, por uma última vez, em 2007”.

Nestes termos, a ameaça à integridade da moeda única expressa o desrespeito pelo modelo político, económico e social europeu e revela o afastamento explícito do modelo da União consensualizado em 2007.

${ }^{32} \mathrm{O}$ confronto entre as redacções do n. ${ }^{\circ} 1$ e do n. ${ }^{\circ} 2$ do art. $^{\circ}$ $119 .^{\circ}$ do TFUE contribui para o esclarecimento do alcance jurídico e económico da hipótese de quebra da integridade da moeda única.

O n. ${ }^{\circ} 1$ do art. $^{\circ} 119 .^{\circ}$ estabelece: "Para alcançar os fins enunciados no $\operatorname{artigo~} 3 .^{\circ}$ do Tratado da União Europeia, a acção dos Estados-Membros e da União implica, nos termos do disposto nos Tratados, a adopção de uma política económica baseada na estreita coordenação das políticas económicas dos Estados-Membros, no mercado interno e na definição de objectivos comuns, e conduzida de acordo com o princípio de uma economia de mercado aberto e de livre concorrência". Por sua vez, o n. ${ }^{\circ}$ 2 determina: "Paralelamente, nos termos e segundo os procedimentos previstos nos Tratados, essa acção implica uma moeda única, o euro, e a definição e condução de uma política monetária e de uma política cambial únicas, cujo objectivo primordial é a manutenção da estabilidade dos preços e, sem prejuízo desse objectivo, o apoio às políticas económicas gerais na União, de acordo com o princípio de uma economia de mercado aberto e de livre concorrência".

De acordo com FERreira (2012, p. 556), “A diferença entre a União Monetária (assente no confisco das políticas cambial e monetária dos EM) e a União Económica (baseada exclusivamente no método tradicional da inter-governamentalidade) é o aspecto mais significativo. A diferente redacção dos n. ${ }^{o s} 1$ e 2 do artigo é, aliás, totalmente esclarecedora, sendo claro que, no primeiro caso, estamos em presença de formas de coordenação de políticas nacionais autónomas, enquanto que, no segundo, se trata da definição de políticas cambiais e monetárias da própria União".

Destarte, a quebra da integridade da moeda única significaria o malogro de políticas cambiais e monetárias da própria União - fundadas no confisco das políticas cambial e monetária dos EM - e não de formas de coordenação de políticas nacionais autónomas - firmadas no método tradicional da inter-governamentalidade -, o que representaria um retrocesso significativo no modelo da União consensualizado no Tratado de Lisboa (cfr. nota anterior). 
consagrado no art. $^{\circ} 3 .^{\circ}$, n. $^{\circ} 3$, do TUE, e reafirmado nos artigos $26 .^{\circ}$, n. ${ }^{\text {os }} 1$ e $2^{33}$, e $119 .^{\circ}$, n. $^{\circ} 1$, do TFUE.

Elucidativamente, a Comunicação da Comissão: Europa 2020 - Estratégia para um crescimento inteligente, sustentável e inclusivo, no subtítulo "A Europa pode ter êxito", sustenta:

"A Europa dispõe de inúmeros trunfos: podemos contar com o talento e a criatividade dos nossos povos, com uma base industrial sólida, um sector dos serviços muito dinâmico, um sector agrícola dinâmico e de grande qualidade, uma forte tradição marítima, o nosso mercado único e a nossa moeda comum, o nosso estatuto de maior bloco comercial do mundo e principal destino do investimento directo estrangeiro" [cfr. Comissão Europeia (2010a, p. 11)].

Saliente-se que "o nosso mercado único" e "a nossa moeda comum" são considerados trunfos na definição da estratégia da União Europeia para 2020. Consequentemente, qualquer ameaça à integridade da moeda única ou à integridade do mercado interno faria perigar os objectivos estratégicos para 2020.

Compreende-se, assim, a apreensão sobre o estado do mercado interno de serviços bancários, registada no "considerando 3» do Regulamento (UE) n. ${ }^{\circ}$ 1024/2013:

“É essencial manter e aprofundar o mercado interno de serviços bancários para fomentar o crescimento da economia na União e o financiamento adequado da economia real.

33 Sobre a criação, a evolução e o sentido do mercado interno, cfr. PORTO (2012, p. 270), que reitera a preferência pela designação de "único" ao invés de "interno", ao sustentar que "é preferível a designação de "único" - na tradução à letra de 'single' market - dando a ideia, correcta e desejável, de que não se trata de um mercado 'fechado', protegido, em relação ao exterior, bem como de que não se trata de um mercado nacional, mas sim de um mercado comum a vários países”. 
Porém, atingir esse objectivo constitui um desafio cada vez maior. A realidade dos factos demonstra que a integração dos mercados bancários na União está a atingir um impasse".

De forma a ultrapassar o impasse, o "considerando 11» do mesmo Regulamento sustenta:

"Deverá portanto ser criada uma união bancária na União, assente num conjunto único de regras exaustivo e pormenorizado para os serviços financeiros no mercado interno como um todo, e composto de um mecanismo único de supervisão e de novos enquadramentos para a garantia de depósitos e a resolução. Atendendo às estreitas ligações e interacções entre os Estados-Membros cuja moeda é o euro, a união bancária deverá aplicar-se, pelo menos, a todos os Estados-Membros da área do euro. $\mathrm{Na}$ medida em que tal seja possível do ponto de vista institucional, e com vista a preservar e aprofundar o mercado interno, a união bancária deverá igualmente ser aberta à participação dos demais Estados-Membros".

Refira-se que os três alicerces da união bancária considerados indispensáveis para a integridade do sistema financeiro e do mercado interno como um todo - Mecanismo Único de Supervisão (MUS), Sistema Comum de Garantia de Depósitos (SGD) e Mecanismo Único de Resolução (MUR) - correspondem aos três domínios de actuação prioritária definidos no Roteiro para uma união bancária, de 12 de Setembro de $2012^{34}$.

34 Cfr. Comissão Europeia (2012a, pp. 3-4). 


\section{O diagnóstico do "Grupo de especialistas de alto nível»}

\subsection{A utilização de instrumentos financeiros complexos}

A proliferação de novos "produtos financeiros»" ${ }^{35}$ foi uma das características que marcou a "revolução financeira» ${ }^{36}$, no final da década de setenta e no início da década de oitenta do século XX. Na verdade, o ritmo de crescimento de novos "produtos financeiros», bem como o seu grau de sofisticação, não pararam de aumentar nas décadas seguintes.

A par dos "produtos financeiros» ${ }^{37}$ de "primeira geração», surgem os de «segunda geração»e os de «terceira geração» ${ }^{38}$, num processo ininterrupto de criação de «novas

35 Sobre o significado da expressão novos "produtos financeiros», cfr. Quelhas (1996, pp. 53-55), onde se refere a "contradição conceptual" inerente à designação de "produtos financeiros» em lugar de «serviços financeiros». Em rigor, os "produtos financeiros» são serviços ou «bens imateriais» e não produtos ou «bens materiais». Porém, a arrogação da materialidade favorece as estratégias de marketing, que presidem à concepção e à distribuição dos serviços financeiros, ao mesmo tempo que mitiga a imaterialidade e a complexidade crescentes dos «produtos financeiros».

36 Sobre o alcance da expressão «revolução financeira», cfr. QuELHAS (1996, pp. 7-32).

37 Sobre a noção, a evolução e as funções dos novos «produtos financeiros», cfr. Quelhas (1996, Capítulo 2 - Novos «produtos financeiros»), mormente: "2.1. As opções”, pp. 55-64; "2.2. Os futuros”, pp. 6483;“2.3. Os forwards”, pp. 83-92;“"2.4. Os swaps”, pp. 93-106.

38 No caso específico do mercado de derivados, ANTUNEs (2008) diferencia as várias espécies ou tipologias de instrumentos derivados de acordo com vários "critérios ordenadores", nomeadamente: o critério do "conteúdo da posição jurídico-contratual", o critério do "conteúdo da sua concepção ou gestação financeira"; o "critério da sua previsão legal"; o "critério da sua criação e negociação"; "o critério do activo subjacente"; "o critério da sua liquidação". 
gerações» de instrumentos financeiros, sucessivamente mais complexos e crescentemente desligados da base material da economia, o que contribuiu impressivamente para a financeirização da actividade económica geral.

No âmbito deste trabalho, interessa sublinhar o segundo critério, ou seja, o do "conteúdo da sua concepção ou gestação financeira", que Antunes (2008, pp. 103-104) define nos seguintes termos: "Segundo este critério, os derivados podem ser ordenados em três grandes famílias ou gerações: os derivados de "primeira geração" - que abrangem os arquétipos de derivados (futuros, opções simples, "swaps”), relativos a activos subjacentes tradicionais (acções, juros, divisas, mercadorias) e primacialmente objecto de liquidação física (entrega do activo contra pagamento do preço) -, os derivados de "segunda geração" - que compreendem variantes ou modalidades especiais daqueles tipos primogénitos (v.g., "forwards", "caps", "floors", derivados de crédito) relativos a outros tipos de activos, sobretudo de natureza financeira e nocional (v.g., índices financeiros, índices económicos, variáveis climatéricas, tarifas de transporte, risco de crédito, etc.), e que são quase exclusivamente objecto de liquidação financeira (pagamento do diferencial de valor) -, e os derivados de "terceira geração" - que designam uma classe de novos produtos financeiros de estrutura híbrida e complexa, resultante da combinação de derivados de primeira e/ou segunda geração (v.g., opções sobre "forwards", "swaptions", "two strike interest rate caps", "foreign exchange contigent forwards", "swaps" exóticos, derivados sobre derivados) ou até de derivados com outros instrumentos financeiros (v.g., "credit-linked notes", "synthetic convertible notes", "interest differential notes")".

A linhagem dos instrumentos derivados evidencia que as sucessivas gerações apresentam graus de imaterialidade e de abstracção crescentes, o que acentua a dicotomia entre a economia real e a economia financeira. Grosso modo, os activos subjacentes e as formas de liquidação vão-se complexificando de geração em geração: os derivados de primeira geração servem de activos subjacentes aos derivados de segunda geração, os quais servem de activos subjacentes aos derivados de terceira geração; os derivados de primeira geração podem ser objecto de liquidação física, ao passo que os de segunda geração e os de terceira geração supõem a liquidação financeira. Mais, os de terceira geração podem combinar diferentes gerações de derivados ou associar derivados com «produtos financeiros» não derivados, o que acentua a sua estrutura híbrida e complexa. 
Em 2007, os instrumentos financeiros complexos desempenharam um papel incontornável na deflagração, na disseminação e no impacto da crise do subprime, como foi o caso dos «produtos financeiros» associados à «titularização» (securitization) de empréstimos hipotecários ${ }^{39}$, nomeadamente os ABS (asset-backed securities) ${ }^{40}$, os MBS (mortgage-backed securities) ${ }^{41}$, os RMBS (residential mortgage-backed securities) ${ }^{42}$, as

39 Sobre o impacto da «titularização» na crise do subprime, cfr. Hellwig (2008), Eggert (2009), Jacobs (2009), Keys, Mukherjee, Seru e Vig (2010), Petersen, Mukuddem-Petersen, De Waal, Senosi e Thomas (2011), Keys, Seru e Vig (2012), Nadauld e Sherlund (2013) e Peicuti (2013).

40 O «glossário bilingue» online do Banco de Portugal traduz ABS - asset-backed security por «instrumento de divida titularizado». Por sua vez, a base online da União Europeia - IATE (Terminologia Interactiva para a Europa) - remete para a expressão «título garantido por activos», usada na Directiva 98/32/CE do Parlamento Europeu e do Conselho, de 22.06.1998.

${ }^{41}$ O Decreto-Lei n. ${ }^{\circ}$ 263/2000, de 18.10.2000, que transpõe para a ordem jurídica portuguesa a Directiva 98/32/CE, do Parlamento Europeu e do Conselho, de 22.06.1998, emprega a expressão «títulos garantidos por créditos hipotecários», à semelhança do Livro Verde - O crédito hipotecário na UE [cfr. Comissão Europeia (2005, p. 6)]. À tradução de mortgage-backed security por "título garantido por créditos hipotecários", a base online da União Europeia - IATE acrescenta a seguinte definição: "Título de dívida coberto pelos fluxos pecuniários de um conjunto de empréstimos hipotecários em geral agregados ao abrigo de uma operação de titularização”.

${ }^{42} \mathrm{O}$ art. 5. ${ }^{\circ}$, n. $^{\circ} 4$, al. b), do Regulamento Delegado (UE) n. ${ }^{\circ}$ 448/2012 da Comissão, de 21.03.2012, que completa o Regulamento (CE) n. ${ }^{\circ}$ 1060/2009 do Parlamento Europeu e do Conselho, no que respeita às normas técnicas de regulamentação para a apresentação das informações que as agências de notação de risco devem disponibilizar num repositório central mantido pela Autoridade Europeia dos Valores Mobiliários e dos Mercados traduz expressamente residential mortgage-backed securities - RMBS por "títulos garantidos por créditos hipotecários para habitação”. Refira-se, ainda, que o Anexo II do mesmo Regulamento subdivide os RMBS em: «HEL» - empréstimos cobertos por uma habitação existente; «PRR» - RMBS prioritários (prime); «NPR»-RMBS subordinados (non prime). 
CDO (collateralized debt obligations) ${ }^{43}$, as CDO squared (collateralized debt obligations squared) ${ }^{44}$, as CDO cubed (collateralized debt obligations cubed) ${ }^{45}$ e os CDS (credit default swaps) ${ }^{46}$.

De forma sucinta, a «titularização» de empréstimos hipotecários metamorfoseia os contratos de mútuo com hipoteca em títulos negociáveis de curto prazo, ou seja, transmuta as operações bancárias activas de longo prazo, contratadas entre os clientes/devedores e os bancos/credores, em valores mobiliários, transaccionáveis junto do público.

A transmutação opera porque os bancos cedem os créditos sobre os seus clientes a SPV (special purpose vehicles) ${ }^{47}$,

${ }^{43} \mathrm{O}$ art. $^{\circ}$ 5, n. ${ }^{\circ} 4$, al. d), do citado Regulamento Delegado (UE) n. ${ }^{\circ} 448 / 2012$ da Comissão, de 21.03.2012, traduz collateralised debt obligations - CDO por "obrigações garantidas por créditos".

${ }^{44}$ Alexandre, Martins, Andrade, Castro e Bação (2009, p. 67) enquadram as "CDO ao quadrado»" nos seguintes termos: "a inovação financeira não se ficou pelas MBS (ou CDO): juntando tranches semelhantes de diferentes MBS, criando-se os "CDO-squared" ("CDO ao quadrado") e posteriormente os "CDO ao cubo", etc. Cada camada de titularização adicionou maior complexidade aos, e aumentou a opacidade dos, produtos financeiros assim criados".

45 Sobre as "CDO ao cubo", cfr. nota anterior.

${ }^{46}$ A base online da União Europeia - IATE apresenta as seguintes alternativas de tradução de credit default swap: "swap de incumprimento de crédito"; "swap de risco de incumprimento de dívida"; "swap de risco de incumprimento"; "seguro contra o risco de incumprimento da dívida". O ponto «3. Tipos de instrumentos derivados de crédito», do Anexo VIII, da Directiva 2006/48/CE do Parlamento Europeu e do Conselho, de 14.06.2006, relativa ao acesso à actividade das instituições de crédito e ao seu exercício traduz expressamente credit default swaps por "swaps de risco de incumprimento" e o ponto 7, da Parte 5, do seu Anexo III estabelece que "o valor de uma posição de risco associada a um swap de risco de incumprimento (credit default swap) consiste no valor nocional do título de dívida de referência, multiplicado pelo prazo de vencimento remanescente desse swap".

47 O Regulamento (CE) n. ${ }^{\circ}$ 1126/2008 da Comissão, de 03.11.2008, que adopta determinadas normas internacionais de contabilidade 
que os agrupam, estruturam, autonomizam e colocam nos mercados de valores mobiliários, sob a forma de unidades de participação, as quais representam fracções de patrimónios autónomos, resultantes de combinações de créditos com diferentes maturidades e com diversos graus de risco.

Em suma, os bancos/cedentes transferem créditos hipotecários de longo prazo para os SPV/cessionários, que os titularizam e colocam no mercado, sob a forma de unidades

nos termos do Regulamento (CE) no 1606/2002 do Parlamento Europeu e do Conselho faz corresponder à sigla inglesa SPE (abreviatura de special purpose entity) a expressão portuguesa "entidade com finalidade especial". A Interpretação SIC 12 - Entidades com Finalidade Especial, anexa ao citado Regulamento (CE) n. ${ }^{\circ}$ 1126/2008, esclarece: “Uma entidade pode ser criada para cumprir um objectivo restrito e bem definido (por exemplo, efectuar actividades de locação, de pesquisa e desenvolvimento ou uma titularização de activos financeiros). Tal entidade com finalidade especial («SPE») pode tomar a forma de uma sociedade, uma parceria ou um trust. As SPE são muitas vezes criadas com acordos jurídicos que impõem limites estritos e por vezes permanentes aos poderes de tomada de decisão do seu órgão directivo, trustee ou gerência sobre as operações da SPE".

Por sua vez, o art. $^{\circ} 13 .^{\circ}$, n. ${ }^{\circ}$ 26, da Directiva 2009/138/CE do Parlamento Europeu e do Conselho, de 25.11.2009, relativa ao acesso à actividade de seguros e resseguros e ao seu exercício (Solvência II) traduz expressamente special purpose vehicle por "entidade instrumental”. Refira-se que a versão francesa da mesma directiva traduz special purpose vehicles por "véhicules de titrisation".

A base online da União Europeia - IATE apresenta duas alternativas de tradução de special purpose vehicle para português: "entidade de finalidade especial" ou "fundo de coinvestimento".

Por último, o Glossário anexo ao Relatório Anual 2008 do BCE emprega a expressão "veículos de titularização", ao definir «titularização» nos seguintes termos: "agregação de activos financeiros, como por exemplo hipotecas residenciais, e a sua posterior venda a veículos de titularização, que por sua vez emitem títulos de rendimento fixo que são vendidos a investidores. O capital e os juros destes títulos dependem dos fluxos de rendimento produzidos pelo conjunto dos activos financeiros subjacentes" - cfr. Banco Central Europeu (2009, pp. 309-310). 
de participação de curto prazo; os SVP pagam a cessão de créditos com o produto da venda das unidades de participação, o que permite aos bancos transformarem activos ilíquidos em liquidez, que redireccionam para novos empréstimos, junto de novos clientes, alavancando consequentemente a respectiva capacidade creditícia.

Na perspectiva dos bancos, a contrapartida pela cessão de créditos a longo prazo representa liquidez, que alavanca imediatamente a sua capacidade creditícia; na perspectiva das SPV, a contrapartida pela selecção de créditos, combinação de maturidades, calibragem de graus de risco e constituição de fundos, bem como pela emissão e colocação de unidades de participação no mercado, representa comissões; na perspectiva do público, a contrapartida pela subscrição de unidades de participação representa um rendimento, cuja fonte reporta aos empréstimos hipotecários originais, tendencialmente mais alto do que o dos juros dos depósitos bancários; na perspectiva do sistema financeiro, a contrapartida pela titularização representa o aumento da liquidez global da economia, a aceleração do ritmo da actividade creditícia e a disseminação do risco do crédito hipotecário pelo mercado.

Sublinhe-se, porém, que a disseminação do risco pelo mercado não garante a sua redução, nem a combinação de créditos, com maturidades e com exposições de risco diversas, assegura a sua neutralização. Assim, as contrapartidas positivas da titularização para os operadores, individualmente considerados, podem ser anuladas ou mesmo ultrapassadas pelas consequências negativas para o sistema, no seu todo, isto é, os benefícios a nível micro analítico não garantem, per se, benefícios a nível macro analítico.

Outra consequência sistémica relevante da titularização é a da redução do spread entre as taxas bancárias passivas e as activas. As taxas bancárias passivas competem com as taxas de remuneração das unidades de participação dos fundos 
de titularização, ou seja, a fidelização dos depositantes trava a descida das taxas de remuneração dos depósitos; as taxas bancárias activas descem por força do aumento da oferta de crédito e da concorrência entre os bancos pela captação de novos mutuários.

Consequentemente, como a descida das taxas activas não é acompanhada pela descida das taxas passivas, o spread dos bancos estreita-se, o que significa ganhos para os clientes bancários. Porém, de novo, os ganhos individuais não implicam necessariamente ganhos colectivos; se é certo que os depositantes preservam os níveis de rendimento e os mutuários baixam os custos do financiamento, também é verdade que o estreitamento do spread diminui a taxa de rendibilidade dos bancos.

Ora, a conjugação entre a diminuição da rendibilidade (via estreitamento do spread) e o aumento da sua capacidade creditícia (via «alavancagem») precipita a concorrência entre os bancos pela captação de novos clientes de crédito, o que degrada os critérios de aferição da qualidade dos novos mutuários. Destarte, a titularização desencadeia um processo acelerado de laxismo da qualidade dos devedores; com efeito, quando os bancos esgotam a capacidade de colocação de novos empréstimos junto dos clientes do segmento prime, viraram-se para os clientes do segmento subprime ${ }^{48}$.

48 Alexandre, Martins, Andrade, Castro e Bação (2009, pp. 63 -65) relacionam a proliferação das operações de titularização no segmento subprime com o financiamento da bolha imobiliária - nos Estados Unidos, em Espanha, na Irlanda e no Reino Unido -, nos seguintes termos: "De 1995 até 2007, o índice subiu 140\% nos EUA, 200\% em Espanha, 260\% no Reino Unido e 310\% na Irlanda. Em último caso, a subida do preço da habitação permitia a quem pediu emprestado e não conseguia cumprir o plano de pagamentos vender a habitação a um preço superior àquele a que tinha comprado, pagar ao banco e ainda lucrar. Se optasse por entregar a habitação ao banco, o banco receberia um activo valorizado e com a perspectiva de se valorizar ainda mais. Num contexto 
Acresce que a manutenção da dinâmica dos processos de titularização exige que o ritmo e o volume das cessões de crédito cresçam incessantemente, sob pena de as contraprestações pagas pelos SVP aos bancos ficarem inactivas, o que geraria espirais de contracção da actividade creditícia. Desta forma, o temor por espirais recessivas intensifica o laxismo da qualidade dos clientes; só que a capacidade dos clientes

como este, parecia que o banco não poderia perder, mesmo que concedesse crédito a clientes aos quais não emprestaria em circunstâncias normais, por não confiar na sua capacidade para cumprir os termos do empréstimo. E, efectivamente, assistiu-se a um relaxar dos requisitos para a atribuição de crédito e ao aumento de crédito concedido ao segmento conhecido por subprime. No segmento subprime encontramos os empréstimos concedidos a indivíduos que não apresentam as características exigidas pelas agências patrocinadas pelo governo norte-americano para financiarem esses empréstimos (segmento prime). Tem sido hábito distinguir uma terceira categoria, situada entre o segmento subprime e o segmento prime e designada por Alt-A, com características intermédias. De $7,2 \%$ e 2,5\% do total dos empréstimos concedidos em 2001, respectivamente, as categorias subprime e Alt- $A$ passaram para $20,1 \%$ e $13,4 \%$ em 2006. Particularmente simbólicos são os empréstimos "ninja": No Income, No Job and No Assets, ou seja, concedidos a pessoas sem declaração de rendimentos, de emprego ou de bens".

De salientar que, no ano anterior à deflagração da crise, o somatório dos empréstimos não classificados como prime ascendia a 33,5\% do total, ou seja, mais de um terço dos empréstimos concedidos pertencia às categorias subprime e Alt-A. O menosprezo do risco pelas instituições de crédito firmou-se em dois argumentos: o crédito hipotecário era classificado de baixo risco pelos credores por força da prestação de garantias reais sobre imóveis pelos devedores; o aumento exponencial dos preços dos imóveis asseverava a integridade do valor dos bens hipotecados.

Mais ainda, à medida que a bolha imobiliária empolava, a atracção dos bancos pelo crédito hipotecário também aumentava, a ponto de os restantes factores de avaliação do risco das operações de mútuo serem desprezados. Só que a concessão crescente de novos créditos hipotecários acelerou a procura de imóveis no mercado, ou seja, a intensificação do ritmo da actividade creditícia alimentou a espiral de subida de preços no sector imobiliário. 
subprime suportarem um choque é substancialmente inferior à dos clientes prime ${ }^{49}$.

49 De forma expressiva, Alexandre, Martins, Andrade, Castro e BAÇÃO (2009, pp. 65-66) salientam: "Em face da possibilidade, oferecida pela titularização e pelas condições no mercado de habitação, de vender a terceiros estes créditos, envolvidos num pacote de rating superior aos dos empréstimos individuais, a qualidade dos créditos concedidos deixou de ser prioritária para os bancos: o importante passou a ser originar créditos para os poder titularizar e distribuir por outros investidores - passou-se assim ao modelo bancário "originar e distribuir" (originate and distribute). A pressão para encontrar clientes do crédito bancário deu origem à acusação de "crédito predatório" (predatory lending): os bancos estariam a emprestar a quem ficaria melhor servido sem o crédito, pessoas que aceitariam o crédito apenas em resultado da pressão do banco e da sua própria falta de «literacia financeira»".

Nestes termos, o modelo «originar e distribuir» configura uma situação de «fuga para a frente» por parte dos bancos. Num processo típico de "desnatação», os bancos começaram por conceder crédito aos clientes do segmento prime, depois aos do segmento $A l t-A$ e finalmente aos do segmento subprime; seria expectável que a descida da qualidade dos devedores significasse a exigência de taxas de juro mais altas, bem como a avaliação mais rigorosa das garantias prestadas. Porém, a cessão de créditos hipotecários a SPV gerou fluxos crescentes de capital para os bancos, que os canalizaram para novos empréstimos hipotecários, junto de devedores não prime, rebaixando os critérios de aferição de risco das operações, não exigindo taxas de juro mais altas, nem garantias mais sólidas.

Destarte, a «fuga para a frente» alimentou a espiral da bolha imobiliária e iludiu os problemas reais subjacentes, nomeadamente os de sobrevalorização dos imóveis dados como garantias e de desajustamento entre as taxas de juro activas das operações e o nível de risco subjacente.

Neste sentido, Alexandre, Martins, Andrade, Castro e Bação (2009, p. 83) põem em evidência que "o aumento em cerca de $80 \%$ dos preços da habitação nos EUA, entre 2000 e 2006, e a expansão dos mercados subprime coincidiram com taxas de juro reais historicamente baixas, sendo mesmo negativas durante grande parte daquele período", ou seja, durante o boom imobiliário, as taxas de juro bancárias activas perderam o papel de indicador do nível de risco das carteiras de crédito. 
Neste cenário, em 2007, quando os primeiros sinais de crise do sector imobiliário despontaram, a fragilidade intrínseca dos clientes subprime emergiu virulentamente.

A aludida metamorfose de empréstimos hipotecários em valores mobiliários criou ilusões adicionais aos vários operadores de mercado; os bancos classificavam os contratos de mútuo com hipoteca como sendo de risco baixo, por força da garantia real subjacente; os SVP consideravam as operações de titularização como sendo de risco baixo, por força da agregação de créditos de vários mutuários, com maturidades desiguais e graus de exposição diferentes; os subscritores encaravam as unidades de subscrição como sendo de risco baixo, por força do profissionalismo dos SVP e da referência a créditos hipotecários na composição das carteiras.

Paradoxalmente, o somatório das classificações de baixo risco pelos operadores não significa um resultado de baixo risco para o mercado, no seu todo, ou seja, a percepção de níveis de risco baixos pelos operadores não elimina o risco sistémico. Similarmente, a obtenção de ganhos individuais de eficiência também não garante, per se, a consecução da eficiência colectiva.

Conquanto revelem maior ênfase nos Estados Unidos, as operações de titularização disseminaram-se por múltiplos países, com variantes específicas e com regimes jurídicos distintos. Recentemente, na União Europeia, o Regulamento (UE) n. ${ }^{\circ} 575 / 2013^{50}$, relativo aos requisitos prudenciais para as instituições de crédito e para as empresas de investimento, e a Directiva 2013/36/UE ${ }^{51}$, relativa ao acesso à actividade das institui-

${ }^{50}$ Cfr. Regulamento (UE) n. ${ }^{\circ}$ 575/2013 do Parlamento Europeu e do Conselho, de 26.06.2013, relativo aos requisitos prudenciais para as instituições de crédito e para as empresas de investimento e que altera o Regulamento (UE) n. ${ }^{\circ}$ 648/2012, publicado no JO, L 176, de 27.06.2013, pp. 1-335.

51 Cfr. Directiva 2013/36/UE do Parlamento Europeu e do Conselho, de 26.06.2013, relativa ao acesso à actividade das instituições de 
ções de crédito e à supervisão prudencial das instituições de crédito e empresas de investimento, atribuíram particular relevo às operações de titularização ${ }^{52}$.

crédito e à supervisão prudencial das instituições de crédito e empresas de investimento, que altera a Directiva 2002/87/CE e revoga as Directivas 2006/48/CE e 2006/49/CE, publicada no JO, L 176, de 27.06.2013, pp. 338-436.

52 Sobre a origem, a evolução e o regime jurídico da securitização ou titularização de créditos, cfr. CALVÃo DA Silva (2013); no âmbito do presente trabalho, cfr., sobretudo, a "Parte IV - No coração da crise financeira global", cujos títulos são per se elucidativos: "Título I: De Alquimia Global a Arma de Destruição Maciça” e "Título II: Revisitação à "Securitization" em Resposta à Crise".

De sublinhar que o Regulamento (UE) n. ${ }^{\circ}$ 575/2013 e a Directiva 2013/36/UE contribuem, nas palavras de CALvão DA Silva (2013, p. 186 e ss.), para a "dessacralização das notações de agências de rating", às quais atribui o epíteto de "pedra angular deste processo alquímico global de engenharia financeira”.

De forma precisa, CALVÃo DA Silva (2013) contrapõe a canonização das agências de rating por Basileia II com a dessacralização das suas notações por Basileia III, no que classifica de "reviravolta da cedência do Direito e da Política ao dogma do mercado e seu benchmarking".

Em 2006, a Directiva 2006/48/CE, do Parlamento Europeu e do Conselho, de 14.06.2006, relativa ao acesso à actividade das instituições de crédito e ao seu exercício, e a Directiva 2006/48/CE, do Parlamento Europeu e do Conselho, de 14.06.2006, relativa à adequação dos fundos próprios das empresas de investimento e das instituições de crédito introduziram, na ordem jurídica comunitária, o Acordo-Quadro relativo à convergência internacional do cálculo e dos requisitos de fundos próprios, do Comité de Supervisão Bancária de Basileia, de 26.06.2004 (Basileia II).

Em 2013, o Regulamento (UE) n. ${ }^{\circ}$ 575/2013, do Parlamento Europeu e do Conselho, de 26.06.2013, relativo aos requisitos prudenciais para as instituições de crédito e para as empresas de investimento e que altera o Regulamento (UE) $n .{ }^{\circ}$ 648/2012, e a Directiva 2013/36/UE, do Parlamento Europeu e do Conselho, de 26.06.2013, relativa ao acesso à actividade das instituições de crédito e à supervisão prudencial das instituições de crédito e empresas de investimento, que altera a Directiva 2002/87/CE e revoga as Directivas 2006/48/CE e 2006/49/CE, adequam a ordem jurídica da União Europeia ao «Acordo Basileia III» - "Basel III:A global regulatory framework 
for more resilient banks and banking systems", de 16.12.2010, revisto em 01.06.2011, e "Basel III:The Liquidity Coverage Ratio and liquidity risk monitoring tools", de 06.01.2013.

A contraposição entre a canonização das agências de rating por Basileia II e a dessacralização das suas notações por Basileia III está explícita nos próprios «considerandos» da Directiva 2013/36/UE que, sublinhe-se, revoga as Directivas 2006/48/CE e 2006/49/CE; com efeito, o "considerando 71» refere: “As Directivas 2006/48/CE e 2006/49/CE constituem um dos pilares em que assentou a dependência excessiva em relação às notações de risco externas. A presente directiva deverá ter em conta as conclusões do G20 e os princípios do CEF relativos à redução da dependência de notações de risco externas. Por conseguinte, as instituições deverão ser incentivadas a usar notações de risco internas, em vez de notações de risco externas, inclusivamente para o cálculo dos requisitos de fundos próprios"; por sua vez, o «considerando 72» acrescenta: “A dependência excessiva de notações de risco externas deverá ser reduzida e os efeitos automáticos delas decorrentes deverão ser gradualmente eliminados. As instituições deverão, pois, ser obrigadas a pôr em prática critérios de concessão de crédito e processos de decisão em matéria de crédito sólidos. As instituições deverão poder utilizar notações de risco externas como um factor entre outros desse processo, mas delas não deverão depender única ou automaticamente".

$\mathrm{Na}$ verdade, o enquadramento da actividade das agências de rating na União Europeia exige a referência ao Regulamento (CE) n. ${ }^{\circ}$ 1060/2009 do Parlamento Europeu e do Conselho, de 16.06.2009, relativo às agências de notação de risco, sucessivamente alterado pelo Regulamento (UE) n. ${ }^{\circ}$ 513/2011, do Parlamento Europeu e do Conselho, de 11.05.2011, pela Directiva 2011/61/UE, do Parlamento Europeu e do Conselho, de 08.06.2011, e pelo Regulamento (UE) n. ${ }^{\circ}$ 462/2013, do Parlamento Europeu e do Conselho, de 21.05.2013.

Em jeito de síntese da fundamentação subjacente à regulamentação europeia comum das agências de rating, refira-se o "considerando 10» do Regulamento (CE) n. ${ }^{\circ}$ 1060/2009, onde se traça simultaneamente uma crítica ao papel das agências de rating na deflagração da crise financeira e um programa de acção para a sua superação, nos seguintes termos: "Considera-se que as agências de notação de risco, por um lado, não reflectiram nas suas notações de risco, numa fase suficientemente precoce, a deterioração das condições do mercado, e, por outro, não ajustaram atempadamente as suas notações de risco na sequência do agravamento 


\subsection{A preponderância do financiamento de curto prazo}

A preponderância do financiamento de curto prazo foi uma das características do sistema financeiro, no período que antecedeu a crise de 2007. Assistiu-se, especialmente, a uma alteração profunda da composição dos balanços dos bancos, quer do lado do passivo, quer do lado do activo.

Do lado do passivo, diminuíram as responsabilidades de longo prazo, sobretudo os depósitos a prazo, e aumentaram as de curto prazo, sob a forma de «novos passivos financeiros»; do lado do activo, diminuíram as operações de crédito a longo prazo, sobretudo os empréstimos, e aumentaram as de curto prazo, sob a forma de «novos activos financeiros $»^{53}$.

Tendencialmente, no balanço dos bancos, subiram as responsabilidades exigíveis a curto prazo e desceram as disponibilidades a longo prazo, ao mesmo tempo que aumentou o peso dos «novos passivos» e dos «novos activos»

da crise dos mercados. A melhor maneira de corrigir essa falha passa por medidas relativas aos conflitos de interesses, à qualidade das notações de risco, à transparência e governação interna das agências de notação de risco e à supervisão das suas actividades. Os utilizadores de notações de risco não deverão confiar cegamente nas mesmas, antes deverão utilizá-las com grande prudência e proceder às suas próprias análises da respectiva fiabilidade, sempre com a devida diligência".

53 A expressão «novos passivos financeiros» alude aos novos «produtos financeiros» de captação de recursos, por contraponto aos tradicionais depósitos bancários, que captam a poupança junto do público a fim de ser canalizada para o investimento, através da intermediação das instituições de crédito.

A expressão «novos activos financeiros» alude aos novos «produtos financeiros» de colocação de recursos, por contraponto aos tradicionais empréstimos bancários, que canalizam a poupança para o investimento, através da intermediação das instituições de crédito.

Sobre o impacto dos "novos instrumentos de dívida» e dos «novos instrumentos de crédito» na crise de 2007, cfr. Pacces (2010), BellofioRe e Halevi (2011) e Simsek (2013). 
financeiros. Destarte, abriu-se caminho à «má combinação de maturidades ${ }^{54}$ e, principalmente, acentuou-se a exposição dos bancos aos «novos produtos» financeiros, mais voláteis, mais complexos e mais efémeros.

O Final Report do High-level Expert Group on reforming the structure of the EU banking sector enfatiza particularmente o financiamento dos bancos nos «short-term wholesale markets» (mercados interbancários de curto prazo) ${ }^{55}$ e a proliferação de «off-balance sheet vehicles» (operações fora do balanço) ${ }^{56}$.

De acordo com o Relatório, o recurso intensivo aos mercados interbancários de curto prazo terá contribuído para a alavancagem de capitais emprestáveis e para a posterior falência de várias bancos, mormente do Northern Rock e do Royal Bank of Scotland.

O financiamento junto dos mercados interbancários aumenta significativamente a capacidade creditícia das instituições de crédito; porém, o recurso intensivo aos mercados interbancários tem consequências sistémicas diferentes da captação de depósitos junto do público em geral.

Com efeito, no mercado interbancário por grosso, as instituições de crédito financiam-se junto de um número reduzido de operadores institucionais, ao passo que, no mercado bancário a retalho, as instituições de crédito financiam-se junto dos seus depositantes. Assim, o recurso intensivo

54 Sobre o problema da «má combinação de maturidades», cfr. Quelhas (2012c), sobretudo em "1.1.3.1.1. O modelo de Diamond e Dybvig", "1.1.3.1.6. O modelo de Calomiris e Kahn" e "1.1.8.3. Os modelos de ataques especulativos de «terceira geração»".

55 Cfr. Liikanen, Bänziger, Campa, Gallois, Goyens, Krahnen, Mazzucchelli, Sergeant, Tuma, Vanhevel e Wijffels (2012), mormente em "3.6.1 Northern Rock” e "3.6.3 Royal Bank of Scotland”.

56 Cfr. Lithanen, Bänziger, Campa, Gallois, Goyens, Krahnen, Mazzucchelli, Sergeant, Tuma, Vanhevel e Wijffels (2012), sobretudo em "2 Aggregate EU Bank Sector Developments" e "3 Diversity of Bank Business Models in Europe". 
aos mercados interbancários aumenta a exposição das instituições de crédito às variações de confiança de um número reduzido de financiadores.

Ao contrário dos modelos tradicionais de «corridas bancárias» ${ }^{57}$, no Northern Rock ${ }^{58}$ ter-se-á assistido à retirada súbita de grandes mutuantes interbancários e não à fuga aos depósitos de pequenos depositantes, cujos levantamentos, no mercado a retalho, foram posteriores à interrupção das operações de financiamento e de refinanciamento, no mercado por grosso.

Nas palavras significativas de LIIKANEN, BänZIGER, CAMpa, Gallois, Goyens, Krahnen, Mazzucchelli, Sergeant, Tuma,VAnhevel e WijfFels (2012, pp. 59-60):

"The immediate cause of the NR [Northern Rock] failure was not a default by its borrowers, nor a run by depositors, but a run by its creditors. The NR case study highlights the relevance of assessing the balance sheet as a whole (leverage, liabilities, maturity mismatch, etc.) and that one needs to look at the overall system as a whole and not merely its individual constituents (that which is micro-prudent can be macro-imprudent). The NR case study offers several other general lessons. First, textbook retail deposit bank runs

57 Sobre os modelos de corridas bancárias, cfr. QuELhas (2012c), sobretudo em "1.1.3.1. Os modelos originais de corridas bancárias", "1.1.3.1.1. O modelo de Diamond e Dybvig", "1.1.3.1.2. O modelo de Waldo", "1.1.3.1.3. O modelo de Gorton", "1.1.3.1.4. O modelo de Jacklin e Bhattacharya", "1.1.3.1.5. O modelo de Chari e Jagannathan", "1.1.3.1.6. O modelo de Calomiris e Kahn", "1.1.3.1.7. O modelo de Carletti”, "1.1.3.1.8. O modelo de Diamond e Rajan”,"1.1.3.2. A extensão dos modelos originais de corridas bancárias", "1.1.3.2.1. O modelo de Garber e Grilli", “1.1.3.2.2. O modelo de Smith”, "1.1.3.2.3. O modelo de De Bandt" e "1.1.3.2.4. O modelo de Temzelides".

58 Sobre as causas da falência do Northern Rock, cfr. SHIN (2009a) e SHIN (2009b). 
à la Diamond and Dybvig (1983) due to coordination failures may not be a good description of modern banking crises. Second, modern banking cannot be viewed separately from (capital) market and macro developments. Third, banking and intermediation is in a constant state of flux and institutions, regulations and laws are important. Fourth, NR is an example of a bank that failed following a period of extremely rapid growth of (credit) activities, excessive reliance on short-term funding and high leverage, which are three of the problematic bank characteristics identified in the literature".

Neste sentido, a causa imediata da falência do Northern Rock não foi o incumprimento dos devedores, nem a fuga dos depositantes, mas sim a corrida dos credores, nos mercados interbancários por grosso, o que evidencia o impacto sistémico da actuação dos operadores institucionais. Destarte, a alteração do modelo de financiamento dos bancos - redução do peso dos depósitos e aumento do recurso aos mercados interbancários - acentuou a fragilidade intrínseca do negócio bancário ${ }^{59}$.

Acresce que a proliferação de off-balance sheets ${ }^{60}$ obscurece a informação sobre os activos e os passivos bancários, ao mesmo tempo que aumenta a "alavancagem do crédito» e mitiga as responsabilidades assumidas. Por exemplo, do lado das operações activas, a titularização transforma activos ilíquidos em liquidez, o que exponencia a capacidade credi-

59 Sobre o aumento do risco sistémico decorrente da alteração do modelo de financiamento dos bancos, cfr. BERGER e BOUWMAN (2009), Demirgüç-Kunt e Huizinga (2010), Bologna (2011), Cornett, McNutt, Strahan e Tehranian (2011), Berger e Bouwman (2013), Bertay, Demirgüç-Kunt e Huizinga (2013) e Demirgüç-Kunt e Huizinga (2013).

60 Sobre o significado e o impacto sistémico das «operações fora do balanço», cfr. QueLHas (2012c, nota 370). 
tícia dos bancos e altera a estrutura dos seus activos; do lado das operações passivas, a negociação de derivados representa a assunção de responsabilidades latentes superiores às inscritas nos seus passivos. Em suma, o risco implícito nestas operações pode ser superior ao explicitado nos balanços dos bancos ${ }^{61}$.

\subsection{A inadequação dos mecanismos de proteção dos depositantes}

A crise financeira de 2007 evidenciou a inadequação dos mecanismos de protecção dos depositantes, quer à escala individual de cada estado-membro, quer à escala comum da União Europeia.

No contexto da construção da União Bancária, assume particular relevo a edificação de um Sistema Comum de Garantia de Depósitos (SGD), considerado um dos três alicerces necessários para a estabilidade e a integridade do mercado interno da UE no domínio dos serviços financeiros, a par do Mecanismo Único de Supervisão (MUS) e do Mecanismo Único de Resolução (MUR) ${ }^{62}$.

Em 12 de Julho de 2010, o Parlamento Europeu e o Conselho apresentaram uma Proposta de Directiva relativa aos sistemas de garantia de depósitos ${ }^{63}$, com o objectivo de reformular a Directiva 2009/14/CE, de 11 de Março de 200964,

61 Sobre o impacto das «operações fora do balanço» na deflagração da crise do subprime, cfr. Acharya e Richardson (2009), Davis (2009), Zaman (2009), Singh (2010), Cooper (2011), Karim, Liadze, Barrell e Davis (2013).

62 Cfr. Comissão Europeia (2012a, pp. 3-4).

63 Cfr. Comissão Europeia (2010b).

${ }^{64}$ Cfr. Directiva 2009/14/CE, do Parlamento Europeu e do Conselho, de 11.03.2009, que altera a Directiva 94/19/CE relativa aos sistemas 
que alterara a Directiva 94/19/CE, de 30 de Maio de $1994^{65}$. As sucessivas remissões evidenciam a mesma preocupação subjacente aos vários diplomas - instituição de um sistema de garantia de depósitos -, mas também demonstram as vicissitudes da União Europeia na resposta à crise financeira de 2007.

Com efeito, o texto originário de 1994 já traçara os objectivos primordiais de um SGD, mormente: $i)$ suprimir todas as restrições à liberdade de estabelecimento e à livre prestação de serviços das instituições de crédito em toda a Comunidade ${ }^{66}$; ii) reforçar a estabilidade do sistema bancário e a proteç̧ão dos aforradores ${ }^{67}$; iii) assegurar um nível mínimo harmonizado de proteç̧ão dos depósitos, independentemente da sua localização no interior da Comunidade $e^{68}$; iv) equiparar a importância da protecção dos depósitos às regras prudenciais para a realização do mercado único bancário ${ }^{69}$.

Acresce que estes objectivos originários fundam-se em pressupostos, que se mantiveram nos textos posteriores, nomeadamente: i) para as instituições de crédito, o custo da participação num sistema de garantia é muito inferior ao que resultaria do levantamento em massa dos depósitos bancários, não só de uma instituição em dificuldades, mas também de instituições com uma situação sã, na sequência de perda de confiança dos depositantes na solidez do sistema bancário ${ }^{70}$; ii) a garantia dos depósitos constitui um elemento fundamental de realização do mercado interno e um

de garantia de depósitos, no que respeita ao nível de cobertura e ao prazo de reembolso, publicada no JO L 68, de 13.03.2009, pp. 3-7.

65 Cfr. Directiva 94/19/CE, do Parlamento Europeu e do Conse1ho, de 30.05.1994, relativa aos sistemas de garantia de depósitos, publicada no JO L 135, de 31.05.1994, pp. 5-14.

${ }^{66}$ Cfr. «considerando 1» da Directiva 94/19/CE, p. 5.

67 Cfr. «considerando 1» da Directiva 94/19/CE, p. 5.

68 Cfr. «considerando 2» da Directiva 94/19/CE, p. 5.

${ }^{69}$ Cfr. «considerando 2» da Directiva 94/19/CE, p. 5.

70 Cfr. «considerando 4» da Directiva 94/19/CE, p. 5. 
complemento indispensável do sistema de supervisão das instituições de crédito, em virtude da solidariedade que cria entre todas as instituições de uma mesma praça financeira em caso de suspensão de pagamentos por parte de qualquer delas ${ }^{71}$.

De sublinhar que, desde 1994, os objectivos da instituição de um SGD não se circunscrevem à esfera micro analítica da protecção dos depositantes, mas ensejam também a esfera macro analítica da evitação de corridas bancárias, da estabilidade sistémica e da realização do mercado único.

Porém, a crise de 2007 desencadeou a quebra de confiança dos depositantes nos bancos e evidenciou a fragilidade do SGD, instituído pela Directiva 94/19/CE, o que suscitou a sua reformulação pela Directiva 2009/14/CE.

A exposição de motivos, que precede o articulado da Directiva 2009/14/CE, enquadra a reforma do SGD no contexto da resposta europeia à crise financeira, ao sublinhar os seguintes objectivos: $i$ ) restabelecer a confiança e o bom funcionamento do sector financeiro ${ }^{72}$; ii) promover a convergência dos sistemas de garantia de depósitos dos estados-membros ${ }^{73}$; iii) aumentar a cobertura do $S G D^{74}$; iv) evitar distorções de concorrência entre estados-membros ${ }^{75}$.

Sublinhe-se que o art. ${ }^{\circ} 1 .^{\circ}$, n. $^{\circ} 3$, da Directiva 2009/14/ $/ \mathrm{CE}$ aumentou o limiar de cobertura, previsto no art. $7 .^{\circ}$, n. ${ }^{\circ}$ 1, da Directiva 94/19/CE, de 20000 para 50000 euros, além de instituir a obrigação de os estados-membros elevarem o mínimo de cobertura para 100000 euros, até 31 de Dezembro de 2010. Por outro lado, o art. 1. ${ }^{\circ}$, n. ${ }^{\circ}$ 6, da Directiva 2009/14/CE reduziu o prazo de reembolso, previsto

\footnotetext{
71 Cfr. «considerando 25» da Directiva 94/19/CE, p. 7.

72 Cfr. «considerando 1» da Directiva 2009/14/CE, p. 3.

73 Cfr. «considerando 1» da Directiva 2009/14/CE, p. 3.

74 Cfr. «considerando 2» da Directiva 2009/14/CE, p. 3.

75 Cfr. «considerando 3» da Directiva 2009/14/CE, p. 3.
} 
no art. ${ }^{\circ} 10$, n. $^{\circ}$ 1, da Directiva 94/19/CE, de três meses para vinte dias úteis.

A subida do limiar de cobertura estende o universo dos depósitos abrangidos e a diminuição do prazo de reembolso reforça a confiança dos depositantes; as duas medidas procuram ainda adequar o quadro legislativo de 1994 ao aumento do volume e da volatilidade das transacções.

Contudo, o regime instituído em 2009 revelou-se insuficiente para a estabilização do sistema bancário, além de não corresponder às exigências da criação da União Bancária. Com o objectivo de superar estes entraves, o Parlamento Europeu e a Comissão apresentaram, em 12 de Julho de 2010, uma Proposta de Directiva relativa aos sistemas de garantia de depósitos ${ }^{76}$.

A «exposição de motivos» da Proposta de Directiva, de 12 de Julho de 2010, começa por denunciar a fragmentação excessiva dos sistemas de garantia de depósitos vigentes nos estados-membros, nos seguintes termos:

“... os acontecimentos de 2007 e 2008 vieram demonstrar que o actual SGD, muito fragmentado, não cumpriu os objectivos fixados pela Directiva 94/19/CE relativa aos sistemas de garantia de depósitos, em termos da manutenção da confiança dos depositantes e da estabilidade financeira em períodos de pressão na economia. Os cerca de 40 SGD actualmente existentes na UE, que abrangem diferentes grupos de depositantes e depósitos e prevêem diferentes níveis de cobertura, impõem obrigações financeiras divergentes aos bancos e, por conseguinte, limitam as vantagens do mercado interno tanto para os bancos como para os depositantes. Além disso, verificou-se que os sistemas não estavam suficientemente financiados para os períodos de tensão financeira” [cfr. Comissão Europeia (2010b, p. 2)].

76 Cfr. Comissão Europeia (2010b). 
De sublinhar a dupla consequência da pluralidade de regimes de protecção dos depositantes, na União Europeia: a capacidade de recuperação da confiança dos depositantes e de estabilização do sistema bancário por meio de sistemas de garantia fragmentados é inferior à de um SGD comum; a diversidade de sistemas de garantia de depósitos é contrária aos objectivos do mercado interno, podendo perigar a sua unidade.

Apesar das alterações introduzidas em 2009 - aumento do nível mínimo de cobertura e redução o prazo reembolso -, a heterogeneidade de regimes prevaleceu como marca de água dos sistemas de garantia de depósitos dos estados-membros.

Compreende-se, assim, que a Proposta de Directiva de 2010 tenha privilegiado as seguintes opções:

" [1] Simplificar e harmonizar o âmbito da cobertura; [2] Reduzir o prazo de reembolso para sete dias; [3] Pôr termo à prática que consiste na compensação dos débitos contra os créditos dos depositantes; [4] Introduzir uma minuta de informação a visar pelos depositantes e uma referência obrigatória aos SGD nos extractos de conta e na publicidade; [5] Harmonizar a abordagem do financiamento dos SGD; [6] Fixar um nível-alvo para os fundos dos SGD; [7] Fixar a proporção das contribuições ex ante e ex post dos bancos para os SGD; [8] Introduzir elementos baseados no cálculo das contribuições dos bancos para os SGD; [9] Limitar a utilização dos fundos dos SGD para fins mais alargados de resolução de crises num banco, em benefício de todos os seus credores; [10] Fazer com que o SGD do país de acolhimento funcione como ponto único de contacto para os depositantes em sucursais noutro Estado-Membro" [cfr. COMISSÃo EuROPEIA (2010b, pp. 4-5)]. 
Algumas das opções assumem particular relevo, quer para a estabilização do sistema bancário, quer para a preservação da integridade do mercado único.

Assim, a opção 1 concretiza-se na obrigatoriedade de todas as instituições de crédito aderirem a um sistema de garantia de depósitos e na sujeição de todos os bancos e de todos os sistemas de garantia dos estados-membros às novas regras da Directiva, bem como na harmonização do conceito de depósito ${ }^{77}$.

77 A redacção do art. $2 .^{\circ}$, n. $^{\circ} 1, \mathbb{S} 1$, da Proposta de Directiva contrasta com a redacção da Directiva de 1994, mantida em 2009. Com efeito, a redacção de 2010 circunscreve a noção de depósitos a "saldos credores resultantes de fundos existentes numa conta ou de situações transitórias decorrentes de operações bancárias normais, que devem ser restituídos pela instituição de crédito nas condições legais e contratuais aplicáveis", eliminando a parte final do parágrafo referente a "dívidas representadas por títulos emitidos pela instituição de crédito".

A mesma preocupação é patente na nova redacção do $\ 3$, segundo o qual "Um instrumento não constitui um depósito em qualquer das seguintes circunstâncias: a sua existência só pode ser demonstrada por um certificado distinto de um extracto de conta; o seu capital não é reembolsável pelo valor nominal; o seu capital só é reembolsável pelo valor nominal no âmbito de uma garantia ou acordo de garantia em particular, facultados pela instituição de crédito ou por terceiros".

Ambas as alterações restringem a noção de depósito a instrumentos inteiramente reembolsáveis, demonstráveis por extracto de conta, excluindo as dívidas tituladas e os "produtos estruturados», que combinam características de diferentes aplicações financeiras.

Destarte, o SGD não cobrirá operações tendencialmente especulativas, o que é reiterado pelo novo "considerando 17», quando refere: "A fim de limitar a protecção dos depósitos ao estritamente necessário para garantir a segurança jurídica e a transparência para os depositantes e de evitar a transferência dos riscos de investimento para os sistemas de garantia de depósitos, alguns produtos financeiros com um carácter de investimento devem ser excluídos da cobertura, em particular os produtos não reembolsáveis pelo seu valor nominal e aqueles cuja existência só pode ser comprovada através de um certificado" [cfr. COMISSÃo EUROPEIA (2010b, p. 16)]. 
A opção 2 reduz para 7 dias o prazo de reembolso, que já fora fixado em 20 dias úteis, em 2009, comprimindo o anterior prazo de 3 meses, estabelecido em 1994, com o objectivo de travar tempestivamente a deflagração de corridas bancárias contagiosas.

A opção 3 traduz-se na revogação das normas de 1994 e de 2009, que permitiam a determinação do montante reembolsável, através da compensação entre créditos, a título de garantia de depósitos, e débitos de que o beneficiário fosse responsável perante o banco, nos casos em que o depositante/garantido fosse simultaneamente contraparte de operações bancárias passivas e activas perante o depositário incumpridor $^{78}$, o que reforça, em si, a protecção dos depósitos.

A opção 4 enquadra-se na publicitação das regras de funcionamento dos $\mathrm{SGD}^{79}$, enquanto forma de protecção dos consumidores financeiros e de salvaguarda da estabilidade sistémica. Note-se que a Proposta de Directiva de 2010 não confunde informação aos depositantes sobre SGD com marketing, ou seja, a sujeição dos bancos a um sistema de garantia comum constitui uma obrigação legal e não um argumento de captação de clientes. Este é um aspecto essencial para a

$78{\text { Cfr. o } \text { art. }^{\circ} \text { 6, n. }}^{\circ} 4$, aditado pela Proposta de Directiva relativa aos sistemas de garantia de depósitos, de 12.07.2010.

79 Cfr. o art. ${ }^{\circ} 14$, n. $^{\circ}$ 2, aditado pela Proposta de Directiva relativa aos sistemas de garantia de depósitos, de 12.07.2010, que remete para o respectivo anexo III (Minuta de informação ao depositante). Sublinhe-se que o texto da minuta dá a conhecer aos depositantes os aspectos essenciais do SGD, nomeadamente: denominação do sistema de garantia responsável pela cobertura dos depósitos; montante máximo de reembolso por banco; forma de agregação dos depósitos do mesmo cliente, no mesmo banco, para determinação do nível de cobertura; especificação das regras aplicáveis a diferentes tipos de contas, nomeadamente contas singulares, contas colectivas, contas de sociedades, contas de agrupamentos destituídos de personalidade jurídica; prazo máximo de reembolso dos depósitos cobertos. 
preservação do mercado único de serviços financeiros, onde a preferência dos depositantes não deve ser condicionada pelo sistema de garantia a que reportam os depositários ${ }^{80}$.

A opção 5 materializa-se nas novas redacções dos artigos 9. (Financiamento dos sistemas de garantia de depósitos) e 10. ${ }^{\circ}$ (Empréstimos entre sistemas de garantia de depósitos) da Proposta de Directiva de 2010.

O art. 9. ${ }^{\circ}$ da Proposta de Directiva prevê a adequação dos recursos financeiros dos SGD às suas responsabilidades potenciais, ao mesmo tempo que harmoniza as respectivas formas de financiamento entre os estados-membros ${ }^{81}$.

${ }^{80}$ Neste sentido, o ponto 7.7 da «Explicação pormenorizada da Proposta» esclarece: "A publicidade de produtos de depósito deve ser limitada a uma referência factual à cobertura pelo SGD, de modo a evitar que os sistemas de garantia sejam utilizados como instrumento de marketing" [cfr. Comissão Europeia (2010b, p. 10)]. Por sua vez, o novo "considerando 28" da Proposta de Directiva de 2010 adverte contra a utilização não regulamentada de menções publicitárias ao SGD, nos seguintes termos: “... os depositantes existentes devem ser informados da cobertura de que beneficiam e do sistema responsável através dos seus extractos de conta e os potenciais novos depositantes devem visar uma minuta de ficha de informação nesse sentido. O teor das informações deve ser idêntico para todos os depositantes. A utilização não regulamentada, para fins publicitários, de referências ao montante e ao âmbito do sistema de garantia de depósitos pode prejudicar a estabilidade do sistema bancário ou a confiança dos depositantes. Assim, a referência aos sistemas de garantia de depósitos em anúncios deve ser limitada a uma curta referência factual. Os sistemas que protegem as próprias instituições de crédito devem informar claramente os depositantes sobre as suas funções, sem prometerem uma protecção ilimitada dos depósitos" [cfr. Comissão Europeia (2010b, pp. 18-19)].

81 O novo "considerando 16» da Proposta de Directiva de 2010 justifica a harmonização das formas de financiamento dos SGD, nos seguintes termos: "É indispensável harmonizar os métodos de financiamento dos sistemas que garantem os depósitos ou as próprias instituições de crédito. Por um lado, o custo do financiamento desses sistemas deve ser suportado principalmente pelas próprias instituições de crédito; por outro lado, 
A fixação do «nível alvo», a definição dos meios de financiamento e a calendarização dos suprimentos são elementos essenciais para o funcionamento eficiente e eficaz dos SGD, nos vários estados-membros.

Por sua vez, o art. $100^{\circ}$ da Proposta de Directiva admite a concessão de empréstimos entre os SGD de diferentes estados-membros, como meio de reforço da protecção dos depositantes e de salvaguarda da estabilidade sistémica. Porém, o mesmo artigo restringe as condições de acesso ao financiamento mútuo, regula as relações entre os sistemas de garantia mutuantes e o sistema de garantia mutuário, estabelece a taxa de juro aplicável, a forma de pagamento de juros e os prazos de reembolso, além de sublinhar a natureza excepcional deste tipo de apoio.

A opção 6 está consagrada no art. $2 .^{\circ}$, n. $^{\circ} 1$, al. h), da Proposta de Directiva de 2010, que fixa o «nível-alvo» em "1,5\% dos depósitos elegíveis para cobertura pelos quais um sistema de garantia de depósitos é responsável”. Caso o «nível-alvo» se revele insuficiente para o reembolso dos depósitos garantidos, o art. ${ }^{\circ} 9 .^{\circ}$ admite o aumento dos recursos à disposição do SGD responsável; assim, a dotação, ex ante, de 1,5\% poderá ser reforçada por contribuições extraordinárias, ex post, até $0,5 \%$, perfazendo um limite de $2 \%$ dos depósitos elegíveis. Quer a dotação inicial, quer as contribuições extraordinárias, serão suportadas pelos bancos/depositários, na proporção dos depósitos elegíveis para cobertura ${ }^{82}$.

as capacidades de financiamento desses sistemas devem ser proporcionais às obrigações que sobre eles recaem. A fim de assegurar que os depositantes em todos os Estados-Membros beneficiem de um mesmo nível de protecção elevado e que os sistemas de garantia de depósitos emprestem dinheiro entre si apenas nos casos em que o sistema que contrai o empréstimo tenha sido sujeito a um esforço financeiro substancial, o financiamento dos sistemas de garantia de depósitos deverá ser altamente harmonizado" [cfr. Comissão Europeia (2010b, p. 16)].

$82 \mathrm{O}$ art. ${ }^{\circ} 4{ }^{\circ}$ da Proposta de Directiva define pela negativa os depósitos elegíveis para cobertura, enunciando os tipos excluídos do SGD, 
A opção 7 está plasmada no art. ${ }^{\circ} 9^{\circ}{ }^{\circ}$, n. ${ }^{\circ} 3$, da Proposta de Directiva, que estabelece a relação entre as contribuições ex ante e as contribuições ex post a pagar pelos bancos para o SGD. Considerando que as contribuições ex ante correspondem a 1,5\% dos depósitos elegíveis e que as contribuições ex post podem atingir 0,5\% dos depósitos elegíveis, só sendo mobilizáveis em caso de insuficiência das dotações iniciais, então as primeiras não representarão menos de $75 \%$ do total das contribuições dos bancos, nem as segundas equivalerão a mais de $25 \%$ desse total.

A opção 8 espelha-se no art. $^{\circ} 11 .^{\circ}$ da Proposta de Directiva de 2010, que estabelece a fórmula de cálculo das contribuições das instituições de crédito para os sistemas de garantia de depósitos ${ }^{83}$. O n. ${ }^{\circ} 1$ do mesmo artigo consagra a correspondência entre a contribuição de cada banco e o respectivo grau de risco, aferível segundo os critérios estabelecidos nos Anexos I e II da referida Proposta. Em regra, as

\footnotetext{
nomeadamente: depósitos feitos por outras instituições de crédito em seu próprio nome e por sua própria conta; «fundos próprios» das instituições de crédito; depósitos decorrentes de operações em relação às quais tenha sido proferida uma condenação penal por branqueamento de capitais; depósitos de instituições financeiras; depósitos de empresas de investimento; depósitos de titulares não identificados; depósitos de empresas seguradoras; depósitos de organismos de investimento colectivo; depósitos de fundos de pensões ou de reforma; depósitos de autoridades; títulos de dívida emitidos por uma instituição de crédito e débitos emergentes de aceites próprios e de promissórias em circulação.

$\mathrm{Na}$ sua maioria, as exclusões do art. $^{\circ} 4 .^{\circ}$ incidem sobre depósitos de operadores institucionais (v.g., instituições de crédito, instituições financeiras, empresas de investimento, seguradoras, organismos de investimento colectivo e fundos de pensões ou de reforma), o que revela o objectivo primordial do SGD de evitar corridas bancárias por parte de depositantes não institucionais.

83 Sobre os modelos de cálculo das contribuições das instituições de crédito para os sistemas de garantias de depósitos, na União Europeia, cfr. Campolongo, Cariboni e Uboldi (2008) e Campolongo, Cariboni, Guilleme Moreno e Uboldi (2009).
} 
contribuições para os SGD aumentam com a subida do grau de risco dos depositários, de forma a dissuadir as operações mais arriscadas e a estabilizar o sistema bancário.

Porém, a Proposta de Directiva não apresenta uma harmonização completa, mas apenas parcial, da fórmula de cálculo das contribuições das instituições de crédito, porque os Anexos I e II diferenciam entre os indicadores de perfil de risco fundamentais, obrigatórios para todos os estados-membros, e os indicadores de perfil de risco suplementares, que têm natureza facultativa.

A opção 9 consta do art. $^{\circ} 9$, n. ${ }^{\circ}$ 5, da Proposta de Directiva, que diferencia entre a utilização de fundos dos SGD para o reembolso dos depositantes e para o resgate dos bancos. Apesar de o objectivo primordial dos SGD ser o da protecção dos depositantes, o referido artigo admite, de forma limitada, a transferência de fundos para a resolução de crises bancárias.

De forma a salvaguardar a função primária de protecção dos depositantes, o apoio à resolução de um banco, através do SGD, fica limitado ao montante dos depósitos cobertos da instituição apoiada e exige o acompanhamento por parte da Autoridade Bancária Europeia.

Porém, a Proposta de Directiva admite, ainda, que os estados-membros autorizem os SGD a utilizarem os seus recursos financeiros para evitar uma situação de incumprimento por um banco, desde que respeitem os requisitos estatuídos no art. $9 .^{\circ}, \mathrm{n} .^{\circ}$ 5, $\int 3$. Assim, os fundos dos SGD podem ser destinados ao financiamento da prevenção de situações de incumprimento bancário e não apenas de resolução de crises, contanto que fique salvaguardada a função primordial de garantia dos depósitos.

A opção 10 está prevista na nova redacção do art. ${ }^{\circ} 12 .^{\circ}$ da Proposta de Directiva, concernente à cooperação no interior da União, e constitui um passo relevante para o reforço do mercado único de serviços bancários. 
De notar que um depósito, constituído numa sucursal estabelecida noutro estado-membro, é garantido pelo SGD do país de origem; porém, os depositantes da sucursal serão reembolsados pelo SGD do país de acolhimento, o qual será ressarcido pelo SGD de origem.

Destarte, os SGD dos estados-membros de acolhimento actuam como «ponto único de contacto», «caixa postal» e «agente pagador» ${ }^{84}$ em relação aos depositantes das sucursais de bancos de outros estados-membros, sem perderem o beneficio da protecção pelos SGD de origem.

Apesar de a Proposta de Directiva relativa aos sistemas de garantia de depósitos remontar a 12 de Julho de 2010, prevê-se que a aprovação só ocorra em $2014^{85}$. A este diferimento acrescem as dilações de transposição, admitidas no art. ${ }^{\circ} 20 .^{\circ}$ da Proposta de Directiva, aplicáveis a algumas das suas medidas

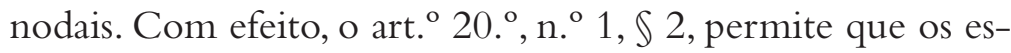
tados-membros protelem a transposição das normas dos artigos $9 .^{\circ}$, n..$^{\text {os }} 1$ e 3 , e $10 .^{\circ}$, relativas ao financiamento dos SGD e aos empréstimos entre SGD, até 31 de Dezembro de 2020, e o art. $^{\circ} 20 .^{\circ}$, n. $^{\circ} 1, \mathbb{S} 3$, estabelece um calendário de exigência gradual da percentagem dos depósitos elegíveis pelo art. ${ }^{\circ}$ 9. ${ }^{\circ},{ }^{\circ}$ 5, que se estende até 2020.

${ }^{84}$ As expressões «ponto único de contacto», «caixa postal» e "agente pagador» são utilizadas no texto da «exposição de motivos», que precede a Proposta de Directiva, de 12 Julho de 2010, o qual esclarece: “A fim de facilitar o processo de reembolso em situações transfronteiriças, o país de acolhimento do SGD actua como ponto único de contacto para os depositantes em sucursais noutro Estado-Membro. Tal inclui não só a comunicação com os depositantes nesse país (na qualidade de «caixa postal») como também os pagamentos por conta do país de origem do SGD (na qualidade de "agente pagador»). Essa função será facilitada por acordos entre os SGD” [cfr. Comissão Europeia (2010b, p. 10)].

85 Cfr. Comunicado de Imprensa da Comissão Europeia, de 17.12.2013 [European Commission (2013, p. 4)]. 
Mas, além da indefinição sobre a entrada em vigor da Directiva, o texto da proposta revela alguma ambiguidade sobre o entendimento de um sistema comum de garantia de depósitos; na realidade, não se consagra um SGD único, mas sim sistemas de garantia de depósitos tendencialmente harmonizados entre os estados-membros ${ }^{86}$.

86 Esta opção é advogada na «exposição de motivos» da Proposta de Directiva, nomeadamente nos «considerandos» 5,6 e 24 .

O confronto entre os «considerandos» 5 e 6 demonstra a evolução do grau de harmonização dos SGD europeus; com efeito, o «considerando 5» retrata a situação de 1994, nos seguintes termos: “A Directiva 94/19/CE baseava-se no princípio da mínima harmonização. Assim, foram criados na União diversos sistemas de garantia de depósitos, com características muito distintas, o que causou distorções no mercado para as instituições de crédito e limitou os benefícios do mercado interno para os depositantes" [cfr. Comissão Europeia (2010b, p. 13)]; por sua vez, o "considerando» 6 esclarece o alcance da Proposta de 2010, da seguinte forma: "A Directiva deverá garantir a igualdade de condições entre as instituições de crédito, a fim de facilitar a compreensão das características dos sistemas de garantia de depósitos por parte dos depositantes e de facilitar um reembolso rápido aos mesmos depositantes por sistemas de garantia de depósitos sólidos e credíveis, em prol da estabilidade financeira. Por conseguinte, a protecção dos depósitos deverá ser harmonizada e simplificada na medida do possível" [cfr. Comissão Europeia (2010b, p. 13)].

A rendição à "medida do possível" é reafirmada no "considerando» 24, que alude a uma "harmonização gradual", nos seguintes moldes: "As contribuições para os sistemas de garantia de depósitos devem ter em consideração o nível de risco a que os seus membros se expõem, de modo a reflectir o perfil de risco de cada banco e a calcular as contribuições de modo equitativo, incentivando um comportamento de menor risco. O desenvolvimento de um conjunto de indicadores fundamentais obrigatórios para todos os Estados-Membros e de um conjunto de indicadores suplementares facultativos permitirá uma harmonização gradual" [cfr. Comissão Europeia (2010b, p. 17)].

Mais recentemente, o Comunicado de Imprensa da Comissão Europeia, de 17.12.2013, reafirma: "It is not envisaged to equip the banking union with a single supranational DGS at this stage. The priority is to 


\subsection{A interconexão entre os bancos europeus}

Uma das características da «revolução financeira» foi a adopção generalizada do princípio da «banca universal», subsequente às medidas de liberalização e de desregulação dos mercados financeiros, iniciadas nos anos oitenta do século $\mathrm{XX}^{8788}$.

reach an agreement on a common network of national deposit guarantee schemes. The proposal on DGS once agreed will ensure that every Member State has a deposit guarantee fund which is properly funded, ex ante. The text also opens the way to a voluntary mechanism of mutual borrowing between the DGSs from different EU countries. This is the only form of mutualisation foreseen at this stage" [EUROPEAN COMMISSION (2013, p. 8)].

${ }^{87}$ Sobre o significado e o alcance do princípio da «banca universal», cfr. Quelhas (2012c), mormente as notas 49 e 379, bem como "1.2. Sobre a diversidade de contributos para a compreensão das crises financeiras" e "3.1.5. A identificação entre risco sistémico e risco de contágio indirecto, na acepção de risco de exposição a choques comuns".

88 Em Portugal, o Decreto-Lei n. ${ }^{\circ}$ 298/92, de 31 de Dezembro, que aprovou o Regime Geral das Instituições de Crédito e Sociedades Financeiras (RGICSF) aboliu a diferenciação entre «bancos comerciais», «bancos de poupança» e «bancos de investimento» e consagrou o princípio da «banca universal». Com efeito, o art. $4 .^{\circ}$, n. $^{\circ} 1$, do RGICSF autoriza os bancos a efectuarem as seguintes operações: a) Recepção de depósitos ou outros fundos reembolsáveis; b) Operações de crédito, incluindo concessão de garantias e outros compromissos, locação financeira e factoring; c) Serviços de pagamento; d) Emissão e gestão de meios de pagamento, tais como cheques em suporte de papel, cheques de viagem em suporte de papel e cartas de crédito; e) Transacções, por conta própria ou da clientela, sobre instrumentos do mercado monetário e cambial, instrumentos financeiros a prazo, opções e operações sobre divisas, taxas de juro, mercadorias e valores mobiliários; f) Participações em emissões e colocações de valores mobiliários e prestação de serviços correlativos; g) Actuação nos mercados interbancários; h) Consultoria, guarda, administração e gestão de carteiras de valores mobiliários; i) Gestão e consultoria em gestão de outros patrimónios; j) Consultoria das empresas em matéria de estrutura do capital, de estratégia empresarial e de questões conexas, bem como consultoria e serviços no domínio da fusão e compra de empresas; $\mathrm{k}$ ) Operações sobre pedras e metais preciosos; 1) Tomada de 
Ao quebrar as fronteiras entre os mercados bancário, monetário, cambial, segurador e de valores mobiliários, a adopção do princípio da «banca universal» não só alargou o objecto de actividade originária de cada banco, como também reconfigurou as relações entre os diferentes operadores, através da proliferação de fusões, aquisições e concentrações, bem como do reforço dos conglomerados financeiros ${ }^{89}$.

Destarte, o risco sistémico acentua-se duplamente: o alargamento do objecto de actividade expõe os activos dos bancos a novos riscos, que extravasam o risco inerente às clássicas operações passivas e activas; a concentração de diferentes actividades num conglomerado dissemina pelo todo o risco de cada uma das partes constitutivas.

A preocupação com a intensificação do risco sistémico perpassa a Directiva 2002/87/CE, de 16 de Dezembro de

participações no capital de sociedades; m) Mediação de seguros; n) Prestação de informações comerciais; o) Aluguer de cofres e guarda de valores; p) Locação de bens móveis, nos termos permitidos às sociedades de locação financeira; q) Prestação dos serviços e exercício das actividades de investimento; r) Emissão de moeda electrónica. Sublinhe-se que as primeiras 18 alíneas do art. ${ }^{\circ} 4 .^{\circ}$, n. $^{\circ} 1$, não constituem uma enumeração taxativa, uma vez que a alínea s) admite que os bancos efectuem "outras operações análogas e que a lei lhes não proíba".

Note-se a referência expressa a instrumentos do mercado monetário e cambial, instrumentos financeiros a prazo, opções e operações sobre divisas, taxas de juro, mercadorias e valores mobiliários, bem como a mediação de seguros, e a prestação dos serviços e exercício das actividades de investimento, o que representa o fim da estanqueidade entre os sectores da banca, dos seguros e dos valores mobiliários. Em suma, o núcleo tradicional da actividade bancária - operações passivas de captação de depósitos e operações activas de concessão de crédito - foi substancialmente reconfigurado e alargado aos mercados monetário, cambial, segurador e de valores mobiliários.

89 Sobre os efeitos sistémicos da proliferação de fusões, aquisições e concentrações e do reforço dos conglomerados financeiros, cfr. QuELHAS (2012c, pp. 384-386). 
2002, relativa à supervisão complementar de instituições de crédito, empresas de seguros e empresas de investimento de um conglomerado financeiro, sucessivamente alterada em 2005, 2008, 2010, 2011 e $2013^{90}$.

As consequências sistémicas da criação de conglomerados financeiros sobre os depositantes, os tomadores de seguros e os investidores são, desde logo, realçadas no "considerando 2» da Directiva 2002/87/CE, que sustenta:

"A recente evolução dos mercados financeiros conduziu à criação de grupos financeiros que fornecem serviços e produtos em diferentes sectores dos mercados financeiros, denominados conglomerados financeiros. Até agora não existia qualquer forma de supervisão prudencial, a nível do grupo, das instituições de crédito, empresas de seguros e empresas de investimento que pertencem a tais conglomerados, nomeadamente quanto à solvência, à concentração dos riscos a nível do conglomerado, às operações intragrupo, aos processos internos de gestão de riscos a nível do conglomerado, e à aptidão e idoneidade dos dirigentes. Alguns destes conglomera-

90 Cfr. Directiva 2002/87/CE do Parlamento Europeu e do Conselho, de 16.12.2002, relativa à supervisão complementar de instituições de crédito, empresas de seguros e empresas de investimento de um conglomerado financeiro e que altera as Directivas 73/239/CEE, 79/267/ /CEE, 92/49/CEE, 92/96/CEE, 93/6/CEE e 93/22/CEE do Conselho e as Directivas 98/78/CE e 2000/12/CE do Parlamento Europeu e do Conselho, publicada no JO L 35, de 11.02.2003, pp. 1-27. O diploma original foi sucessivamente alterado pela Directiva 2005/1/CE do Parlamento Europeu e do Conselho, de 09.03.2005, pela Directiva 2008/25/ /CE do Parlamento Europeu e do Conselho, de 11.03.2008, pela Directiva 2010/78/UE do Parlamento Europeu e do Conselho, de 24.11.2010, pela Directiva 2011/89/UE do Parlamento Europeu e do Conselho, de 16.11.2011, e pela Directiva 2013/36/UE do Parlamento Europeu e do Conselho, de 26.06.2013. Em 17.07.2013, o Serviço das Publicações da União Europeia disponibilizou, na base EUR-Lex, a versão consolidada da Directiva 2002/87/CE. 
dos encontram-se entre os maiores grupos financeiros activos nos mercados financeiros e prestam serviços a nível mundial. Se tais conglomerados, nomeadamente as instituições de crédito, empresas de seguros e empresas de investimento que pertencem a estes conglomerados, forem confrontados com dificuldades financeiras, estas poderiam desestabilizar seriamente o sistema financeiro e afectar os depositantes, os tomadores de seguros e os investidores".

De sublinhar que a formação de conglomerados propiciou economias de escala, nos mercados internos e externos, e ganhos de eficiência, traduzidos na criação de sinergias e na redução de custos operacionais, que se repercutiram positivamente sobre os prestadores e sobre os clientes de serviços financeiros. Destarte, subiram as margens de lucro operacionais dos prestadores e desceram os custos suportados pelos clientes, proporcionando vantagens mútuas e crescimento do volume de transacções. Porém, os ganhos de eficiência foram acompanhados por perdas de segurança, suscitando o trade-off entre a eficiência do mercado e a segurança do sistema financeiro.

A propagação intersectorial do risco sistémico, através dos conglomerados financeiros, também constitui uma das preocupações do "pacote legislativo» europeu de Novembro de 2010 e dos diplomas constitutivos da união bancária.

Com efeito, o art. $^{\circ} 2 .^{\circ}$, n. $^{\circ} 3$, do Regulamento (UE) n. ${ }^{\circ}$ 1093/2010 estabelece o dever de cooperação entre a Autoridade Bancária Europeia, o Comité Europeu de Risco Sistémico, a Autoridade Europeia dos Seguros e Pensões Complementares de Reforma e a Autoridade Europeia dos Valores Mobiliários e dos Mercados, na área da supervisão dos conglomerados financeiros e noutras questões intersectoriais, através da participação no Comité Conjunto das Autoridades Europeias de Supervisão. Nos termos do $\operatorname{art}^{\circ}{ }^{\circ}{ }^{\circ}{ }^{\circ},{ }^{\circ}{ }^{\circ} 3$, al. e), do 
Regulamento (UE) n. ${ }^{\circ}$ 1092/2010, o «Comité Conjunto» é parte integrante do Sistema Europeu de Supervisão Financeira e tem as suas competências especificadas nos Regulamentos (UE) n. ${ }^{\circ}$ 1093/2010, (UE) n. ${ }^{\circ}$ 1094/2010 e (UE) n. ${ }^{\circ} 1095 / 2010^{91}$.

Por sua vez, o «considerando 26» do Regulamento (UE) n. ${ }^{\circ}$ 1024/2013, que confere ao BCE atribuições específicas no que diz respeito às políticas relativas à supervisão prudencial das instituições de crédito, realça o impacto desestabilizador sistémico dos conglomerados financeiros, nos seguintes termos:

"Os riscos para a segurança e a solidez de uma instituição de crédito podem surgir quer ao nível de uma instituição de crédito individual, quer ao nível de um grupo bancário ou conglomerado financeiro. É importante adoptar mecanismos de supervisão específicos para atenuar estes riscos e para garantir a segurança e a solidez das instituições de crédito. Para além da supervisão das instituições de crédito individuais, as atribuições do BCE deverão incluir a supervisão a nível consolidado, a supervisão complementar, a supervisão das companhias financeiras e a supervisão das companhias financeiras mistas, com exclusão da supervisão das empresas de seguros".

91 O Regulamento (UE) n. ${ }^{\circ}$ 1093/2010, que cria a Autoridade Bancária Europeia, o Regulamento (UE) n. ${ }^{\circ}$ 1094/2010, que cria a Autoridade Europeia dos Seguros e Pensões Complementares de Reforma, e o Regulamento (UE) n. ${ }^{\circ}$ 1095/2010, que cria a Autoridade Europeia dos Valores Mobiliários e dos Mercados, partilham ipsis verbis alguns dos considerandos e vários artigos, incluindo a numeração e as epígrafes, como é o caso dos artigos $54 .^{\circ}$ a $61 .^{\circ}$, relativos aos organismos conjuntos das autoridades europeias de supervisão. 
O excerto sublinha o alargamento do âmbito originário da "supervisão das instituições de crédito individuais" 92 para a "supervisão a nível consolidado" "93, a "supervisão

92 O art. $^{\circ}$ 2. ${ }^{\circ}$, ponto 3, do Regulamento (UE) n. ${ }^{\circ}$ 1024/2013, remete a definição de «instituição de crédito» para a acepção do art. ${ }^{\circ}$ 4. ${ }^{\circ}$, n. ${ }^{\circ}$ 1, ponto 1, do Regulamento (UE) n. ${ }^{\circ}$ 575/2013, que apresenta a seguinte noção: "uma empresa cuja actividade consiste em aceitar do público depósitos ou outros fundos reembolsáveis e em conceder crédito por conta própria”. Esta noção representa a intermediação bancária clássica de canalização da poupança para o investimento e compreende as operações bancárias passivas de captação de fundos reembolsáveis junto do público e as operações bancárias activas de concessão de crédito.

$93 \mathrm{O}$ art. ${ }^{\circ}$ 4. ${ }^{\circ}$, n. ${ }^{\circ}$ 1, al. g), do Regulamento (UE) n. ${ }^{\circ}$ 1024/2013, atribui ao BCE competência para "Exercer a supervisão em base consolidada das empresas-mãe das instituições de crédito estabelecidas num dos Estados-Membros participantes, inclusivamente das companhias financeiras e das companhias financeiras mistas, e participar na supervisão em base consolidada, incluindo nos colégios de supervisores, sem prejuízo da participação das autoridades nacionais competentes nesses colégios como observadores, no que diz respeito às empresas-mãe não estabelecidas num Estado-Membro participante". Por sua vez, a al. i) do mesmo artigo acrescenta que compete ao BCE "Exercer atribuições de supervisão no que respeita aos planos de recuperação e a uma intervenção precoce quando uma instituição de crédito ou grupo de que o BCE seja a autoridade responsável pela supervisão em base consolidada não satisfaz ou está em risco de infringir os requisitos prudenciais aplicáveis, bem como apenas nos casos expressamente previstos na legislação aplicável da União relativamente às autoridades competentes, no que respeita às mudanças estruturais exigidas às instituições de crédito para prevenir situações de tensão financeira ou incumprimento, excluindo quaisquer poderes de resolução”.

Destarte, a supervisão de base consolidada não é apenas um instrumento de salvaguarda da solidez dos conglomerados e das instituições individuais que os compõem, mas também uma forma de preservação da estabilidade do sistema financeiro no seu todo.

A liberalização e a desregulamentação dos mercados financeiros, a criação de «novos produtos», a adopção do princípio da «banca universal» e a interconexão entre instituições originárias de diferentes segmentos do mercado intensificaram os canais de contágio e propiciaram a propagação 
complementar" 94 , a "supervisão das companhias financeiras"95 e a "supervisão das companhias financeiras mistas" 96.

das dificuldades individuais para os grupos e destes para o sistema. Neste contexto, a supervisão de base individual ocultaria a exposição de cada instituição ao risco sistémico, podendo induzir opções de gestão erróneas pelos administradores e actuações desajustadas ou contraproducentes pelos supervisores.

94 O art. $^{\circ} 4 .^{\circ}$, n. $^{\circ}$ 1, al. h), do Regulamento (UE) n. ${ }^{\circ}$ 1024/2013, atribui ao BCE competência para "Participar na supervisão complementar de um conglomerado financeiro em relação às instituições de crédito que dele fazem parte e assumir as atribuições de coordenação quando o BCE for nomeado coordenador relativamente a um conglomerado financeiro, de acordo com os critérios estabelecidos na legislação aplicável da União”. A matéria relativa à supervisão complementar de instituições de crédito, empresas de seguros e empresas de investimento de um conglomerado financeiro é regida pela Directiva 2002/87/CE do Parlamento Europeu e do Conselho, de 16.12.2002, alterada sucessivamente pela Directiva 2005/1/CE, pela Directiva 2008/25/CE, pela Directiva 2010/78/UE, pela Directiva 2011/89/UE e pela Directiva 2013/36/UE.

$95 \mathrm{O}$ art. ${ }^{\circ}$ 2. $^{\circ}$, ponto 4, do Regulamento (UE) n. ${ }^{\circ}$ 1024/2013 define «companhia financeira» na acepção do art. $^{\circ} 4 .^{\circ},{ }^{\circ} .^{\circ} 1$, ponto 20 , do Regulamento (UE) n. ${ }^{\circ}$ 575/2013, que apresenta a seguinte noção: "uma instituição financeira cujas filiais sejam exclusiva ou principalmente instituições ou instituições financeiras, sendo pelo menos uma destas filiais uma instituição, e que não seja uma companhia financeira mista”. O alcance desta definição exige a mobilização dos seguintes conceitos: «instituição» [art. ${ }^{\circ} 4 .^{\circ}$, n. $^{\circ}$ 1, ponto 3, do Regulamento (UE) n. ${ }^{\circ}$ 575/2013]; «instituição financeira» art. $^{\circ} 4^{\circ} .^{\circ}$, n. ${ }^{\circ} 1$, ponto 26 , do Regulamento (UE) n. ${ }^{\circ} 575 / 2013$ ]; «filial» art. $^{\circ} 4 .^{\circ}$, n. $^{\circ} 1$, ponto 16 , do Regulamento (UE) n. ${ }^{\circ}$ 575/2013]; "Companhia financeira mista» [art. ${ }^{\circ} 4 .^{\circ},{ }^{\circ}{ }^{\circ} 1$, ponto 21 , do Regulamento (UE) n. ${ }^{\circ}$ 575/2013].

Note-se que o Regulamento (UE) n. ${ }^{\circ}$ 575/2013 não prima pela clareza de conceitos, nem pela concisão e coerência da técnica legislativa; com efeito, só o art. $^{\circ} 4^{\circ}{ }^{\circ}$, n, ${ }^{\circ} 1$, contém 128 definições, algumas com várias alíneas e sucessivas remissões internas e externas.

$96 \mathrm{O}$ art. $^{\circ} 4^{\circ}{ }^{\circ}$ n. $^{\circ} 1$, ponto 21 , do Regulamento (UE) n. ${ }^{\circ}$ 575/2013, define "companhia financeira mista» através da remissão para a acepção do art. $^{\circ}$ 2. $^{\circ}$, ponto 15, da Directiva 2002/87/CE, que apresenta a seguinte noção: "uma empresa-mãe que não seja uma entidade 
Além de potenciarem a propagação intersectorial do risco sistémico, os conglomerados financeiros exponenciam também o impacto financeiro das operações de resgate a favor de instituições consideradas «too big to fail ${ }^{97}$.

Os conglomerados financeiros acentuam ainda a padronização de procedimentos, no seio do mesmo grupo, ou a mimetização de comportamentos, entre grupos diferentes, o que propicia o "efeito de contágio», intensifica o risco sistémico e aumenta a probabilidade de deflagração de crises.

Num artigo intitulado "Regulators should encourage more diversity in the financial system", GOODHART e WAGNER (2012) alertam para o risco da homogeneização da actividade das instituições financeiras, sobretudo as de maior dimensão e que actuam em mercados globais.

De forma elucidativa, Goodhart e Wagner (2012) sustentam:

"This lack of diversity is very costly for society. Similar institutions are likely to encounter problems at the same time. This makes systemic crises - such as the crisis of 20072009 - more likely. After all, we are not concerned with isolated bank failures but only with systemic events where a large part of the financial system comes under severe strain.

regulamentada, a qual, em conjunto com as suas filiais - em que pelo menos uma deve ser uma entidade regulamentada com sede estatutária na União - e outras entidades, constitui um conglomerado financeiro".

$\mathrm{Na}$ verdade, a definição de "companhia financeira mista» esvai-se num emaranhado de conceitos e de remissões internas e externas. De facto, a definição apresentada mobiliza as seguintes noções: «entidade regulamentada» art. $^{\circ}$ 2. $^{\circ}$, ponto 4 , da Directiva 2002/87/CE]; «empresa-mãe» [art. ${ }^{\circ} 2 .^{\circ}$, ponto 9, da Directiva 2002/87/CE]; «empresa filial» [art. ${ }^{\circ}$ 2. $^{\circ}$, ponto 10 , da Directiva 2002/87/CE]; «conglomerado financeiro» [art. ${ }^{\circ}$ 2. $^{\circ}$, ponto 14 , da Directiva 2002/87/CE].

97 Sobre as causas e as consequências da política do «too big to fail», cfr. Quelhas (2012a, pp. 247-248). 
When many institutions are facing difficulties, the policy options are very limited as regulators cannot afford to let a large number of institutions fail.

A more homogenous financial system also means that contagion effects are likely to be more pronounced. This is because a failure of one institution is then more likely to occur at times when other institutions are operating under stress. As a result, spillovers from institutional failures will be larger".

Nestes termos, a homogeneização das actividades expõe as diferentes instituições aos mesmos riscos, o que potencia os efeitos desestabilizadores sistémicos da falência de uma delas e pressiona as autoridades monetárias e financeiras a executarem operações de resgate.

Aliás, o excerto não refere apenas a política do «too big to fail», mas alude também à do "too many to fail»" ${ }^{98}$ e acrescenta ainda a do «demasiado semelhante para falir».

${ }^{98}$ A expressão «too many to fail» foi consagrada por ACHARYA e Yorulmazer (2007), no artigo "Too many to fail - An analysis of time-inconsistency in bank closure policies".

As consequências sistémicas da falência de um banco grande são maiores do que as da falência de um banco pequeno, o que justifica a política do «too big to fail». Consequentemente, as autoridades monetárias e financeiras tendem a não resgatar um banco pequeno; porém, se vários bancos pequenos estiverem em risco de falir, as consequências desestabilizadoras sistémicas acentuam-se, o que já justifica os resgates e a adopção da política do «too many to fail». Destarte, os bancos pequenos são estimulados a adoptarem comportamentos comuns porque a probabilidade de serem resgatados aumenta se o número de bancos em risco de falir também aumentar.

No mesmo sentido, Brunnermeier, Crocket, Goodhart, Persaud e SHIN (2009, pp. 27-28) referem a expressão "Systemic in a Herd", ou seja, instituições que não têm relevo sistémico, quando individualmente consideradas, mas que adquirem relevo sistémico, quando consideradas em grupo. Destarte, a acentuação da interconexão entre os bancos, mormente 
Em suma, a interconexão estreita entre os bancos europeus acentua o risco sistémico à escala da União Europeia, quer porque favorece a criação de conglomerados financeiros, considerados «too big to fail», quer porque propicia a adopção de comportamentos miméticos pelas instituições de crédito, consideradas "too many to fail», quer porque empola a oferta bancária homogeneizada, considerada «demasiado semelhante para falir».

\section{3. «Banca universal» ou (re)especificidade e (re)espe- cialização do sector bancário?}

As questões debatidas ao logo deste trabalho confluem na pergunta disjuntiva final, que encabeça o último ponto: «banca universal» ou (re)especificidade e (re)especialização do sector bancário?

O Final Report do High-level Expert Group on reforming the structure of the EU banking sector problematiza as consequências da adopção generalizada do princípio da «banca universal» sobre a estabilidade do sistema bancário europeu $^{99}$. Neste contexto, destacam-se duas das recomendações do High-level Expert Group, a saber: i) a separação entre as «operações por conta própria» e as «operações por conta dos clientes»; ii) a obrigação de elaboração de planos de recuperação e de resolução de bancos.

A primeira recomendação advoga a atribuição das «operações por conta própria» (proprietary trading) ${ }^{100}$ a uma entidade

a decorrente da adopção de comportamentos comuns e da exposição aos mesmos segmentos de mercado, aumentaria o risco sistémico.

99 Cfr. Liikanen, Bänziger, Campa, Gallois, Goyens, Krahnen, Mazzucchelli, Sergeant, Tuma, Vanhevel e Wijffels (2012, p. iii).

100 Sobre o significado e o alcance desestabilizador sistémico do proprietary trading, cfr. Burson (2011), Kregel (2011) e Merkley e Levin (2011). 
jurídica diferente, sempre que o volume destas transacções ultrapasse um patamar de referência. Assim, as «operações por conta dos clientes» seriam mantidas na esfera originária do banco e as "operações por conta própria», que ultrapassem o referido patamar, seriam adstritas a uma entidade adrede criada.

O objectivo da medida é o de seccionar as operações especulativas das operações bancárias clássicas, de forma a evitar que as actividades tradicionais das instituições de crédito sejam contaminadas pelo proprietary trading.

A proposta não enseja apenas a salvaguarda interna dos balanços dos bancos, mas também a protecção dos seus clientes, sobretudo dos seus depositantes, e ainda a própria estabilidade externa do sistema bancário. Com efeito, a preservação da integridade dos activos permite aos bancos o cumprimento pontual das suas responsabilidades, mormente o reembolso dos depositantes, o que evita o recurso ao sistema de garantia de depósitos e, em última instância, a deflagração de corridas bancárias.

A aplicação desta medida quebra materialmente o princípio da «banca universal», apesar de o Final Report do High-level Expert Group admitir que a entidade, propositadamente criada para negociar as "operações por conta própria», seja constituída no seio do mesmo grupo bancário ${ }^{101}$, o que reforça a importância da supervisão consolidada dos conglomerados financeiros.

Assim, o Final Report tenta conciliar a atribuição das «operações por conta própria» e das «operações por conta dos clientes» a entidades jurídicas separadas com a manutenção dessas entidades no seio do mesmo grupo financeiro, aduzindo o argumento da vantagem da preservação da oferta integral de serviços aos clientes.

101 Cfr. Litkanen, Bänziger, Campa, Gallois, Goyens, Krahnen, Mazzucchelli, Sergeant, Tuma,Vanhevel e Wijffels (2012, pp. iv-vii). 
Mas, em abono da verdade, o seccionamento legal do proprietary trading das restantes actividades bancárias representa um revés para o princípio da «banca universal», que se generalizara após a «revolução financeira» dos anos oitenta do século $\mathrm{XX}^{102}$.

A segunda recomendação preconiza a adopção da Proposta de Directiva do Parlamento Europeu e do Conselho que estabelece um enquadramento para a recuperação e resolução de

${ }^{102}$ Em Portugal, o art. $^{\circ} 4 .^{\circ}$, n. $^{\circ}$ 1, do Regime Geral das Instituições de Crédito e Sociedades Financeiras, aprovado pelo DL n. ${ }^{\circ}$ 298/92, de 31 de Dezembro, consagrou o princípio da «banca universal». A consulta do preâmbulo do diploma de 1992 evidencia o contexto nacional e internacional da época; cfr., v.g., os seguintes parágrafos: "O sistema financeiro nacional tem vindo a ser objecto, ao longo da última década, de uma profunda e gradual transformação estrutural que corresponde a uma verdadeira revolução do seu quadro regulamentar e institucional e, bem assim, do respectivo regime de concorrência" [ [ $\left.3 .^{\circ}\right]$; "A rápida e sustentada dinâmica de crescimento económico dos últimos anos criou um contexto particularmente favorável à expansão e reforço da solidez das instituições de crédito, quer públicas, quer privadas, bem como ao desenvolvimento e sofisticação das operações de intermediação financeira" [S 4. ${ }^{\circ}$; "Consolidada a liberalização do mercado interno e tendo as instituições de crédito reagido muito positivamente aos estímulos de um mais agressivo regime de concorrência, o ano de 1992 marca a entrada do processo de liberalização externa na fase de maturidade" [ $\left[5 .^{\circ}\right]$; "Na delimitação do objecto ou âmbito de actividade dos bancos, foi acolhido, na sua quase amplitude máxima, o modelo da banca universal (artigo 4. ${ }^{\circ}$ ) $\left[\int 10 .^{\circ}\right]$.

Parafraseando os últimos excertos, sublinhe-se que, em Portugal, o modelo da banca universal foi acolhido, em 1992, na sua quase amplitude máxima, após uma década de verdadeira revolução do quadro regulamentar e institucional, caracterizada pela concorrência, pelo desenvolvimento e sofisticação das operações de intermediação financeira e pela liberalização dos mercados interno e externo.

Destarte, a proposta de separação entre as «operações por conta própria» e as "operações por conta dos clientes», apresentada pelo High-level Expert Group on reforming the structure of the EU banking sector, em 2012, simboliza, grosso modo, um recuo de vinte anos. 
instituições de crédito e empresas de investimento, apresentada em 6 de Junho de $2012^{103}$. Não obstante, o Final Report do High-level Expert Group, de 2 de Outubro de 2012, aconselha o aprofundamento do teor da Proposta de Directiva, sempre que esteja em causa a continuidade operacional de funções bancárias essenciais.

Neste sentido, o High-level Expert Group sustenta:

“... despite these important initiatives and reforms, the Group has concluded that it is necessary to require legal separation of certain particularly risky financial activities from deposit-taking banks within the banking group. The activities to be separated would include proprietary trading of securities and derivatives, and certain other activities closely linked with securities and derivatives markets $[\ldots]$. The Group also makes suggestions for further measures regarding the bank recovery and resolution framework, capital requirements and the corporate governance of banks. The objective is further to reduce systemic risk in deposit-banking and investment-banking activities, even when they are separated.

The central objectives of the separation are to make banking groups, especially their socially most vital parts (mainly deposit-taking and providing financial services to the non-financial sectors in the economy) safer and less connected to trading activities; and, to limit the implicit or explicit stake taxpayer has in the trading parts of banking groups. The Group's recommendations regarding separation concerns businesses which are considered to represent the riskiest parts of investment banking activities and where risk positions can change most rapidly.

Separation of these activities into separate legal entities is the most direct way of tackling banks' complexity and interconnectedness. As the separation would make banking

103 Cfr. Comissão Europeia (2012c). 
groups simpler and more transparent, it would also facilitate market discipline and supervision and, ultimately, recovery and resolution" [cfr. LiIKAnen, Bänziger, CAmpa, Gallois, Goyens, Krahnen, Mazzucchelli, Sergeant, Tuma, VanheVEL e WijFfels (2012, p. 100)].

De sublinhar que a segunda medida reforça a separação entre as "operações por conta própria» e as «operações por conta dos clientes», ao advogar o alargamento do seccionamento legal a outras actividades bancárias, nomeadamente às transacções sobre valores mobiliários e derivados, quando esteja em causa a estabilidade sistémica.

Mas, se as operações bancárias clássicas, por um lado, e as operações sobre valores mobiliários e derivados, por outro, forem adstritas a entidades diversas, então, restaura-se a diferenciação entre bancos comerciais e bancos de investimento, anterior à adopção do princípio da «banca universal». Destarte, reestabelece-se o "princípio da especialização» das instituições financeiras ${ }^{104}$, que fora afastado pela «revolução financeira» da década de oitenta do século XX.

Acresce que a aplicação do "princípio da especialização» facilitaria a elaboração de planos de recuperação e de resolução de bancos, adequando-os às especificidades dos respectivos objectos negociais. Assim, gizar-se-iam medidas diferenciadoras, consoante os efeitos disruptivos sistémicos das actividades desenvolvidas por cada banco, segregando as operações de intermediação bancária clássicas das transacções especulativas sobre «novos produtos» financeiros.

Consequentemente, a função de canalização da poupança para o investimento, através da captação de depósitos e da concessão de crédito, seria protegida do "efeito de contágio» directo das operações financeiras especulativas, complexas e

104 Sobre o "princípio da especialização» das instituições financeiras, cfr. QuelHAS (1996, pp. 15-32). 
voláteis, o que salvaguardaria os interesses dos aforradores e dos investidores e contribuiria para a estabilidade da economia real.

Em suma, a resposta à crise financeira de 2007 reintroduziu o debate em torno da separação entre bancos comerciais e bancos de investimento, indiciando um movimento pendular de segregação, agregação e desagregação de funções ${ }^{105}$.

Grosso modo, antes da «revolução financeira», a regulação dos mercados financeiros foi acompanhada pela segregação de funções entre bancos comerciais e de investimento; após a «revolução financeira», a desregulação dos mercados financeiros foi acompanhada pela agregação de funções dos bancos comerciais e de investimento; e, por último, a resposta à crise do subprime suscitou a (re)regulação dos mercados financeiros e a desagregação de funções entre bancos comerciais e de investimento.

\section{REFERÊNCIAS BIBLIOGRÁFICAS}

Acharya, Viral V. e Richardson, Matthew (2009): "Causes of the Financial Crisis", em Critical Review: A Journal of Politics and Society, Vol. 21, n. ${ }^{\circ} 2-3$, Special Issue: Causes of the Financial Crisis, Junho, pp. $195-210$.

Acharya, Viral V. e Yorulmazer, Tanju (2007): “Too many to fail - An analysis of time-inconsistency in bank closure policies", em Journal of Financial Intermediation, Vol. 16, n. ${ }^{\circ}$ 1, Janeiro, pp. 1-31.

Alexandre, Fernando, Martins, Ives Gandra, Andrade, João Sousa, Castro, Paulo Rabello e Bação, Pedro (2009): A Crise Financeira Internacional, Coimbra, Imprensa da Universidade de Coimbra.

105 Sobre a separação de funções entre os bancos comerciais e os bancos de investimento, cfr. Morrison (2009), Wilmarth JR. (2009), Carpenter e Murphy (2010a), Carpenter e Murphy (2010b), Kregel (2010a), Kregel (2010b), Focarelli, Marques-Ibanez e Pozzolo (2011) e MAYER (2011) 
Allen, Franklin e Herring, Richard J. (2001): "Banking Regulation versus Securities Market Regulation”, Center for Financial Institutions Working Papers, n. ${ }^{\circ}$ 01-29, Julho, Filadélfia, Wharton School Center for Financial Institutions, University of Pennsylvania, $55 \mathrm{pp}$.

Antunes, José A. Engrácia (2008): “Os Derivados”, em Cadernos do Mercado de Valores Mobiliários, n. ${ }^{\circ}$ 30, Agosto, pp. 91-136.

Banco Central Europeu (2009): Relatório Anual - 2008, Frankfurt am Main, Banco Central Europeu.

Bartholomew, Philip F. e Whalen, Gary W. (1995): "Fundamentals of Systemic Risk", em Banking, Financial Markets, and Systemic Risk, org. por Kaufman, George G., Greenwich, Connecticut, JAI Press, pp. 3-17.

Bellofiore, Riccardo e Halevi, Joseph (2011): “A Minsky moment? The subprime crisis and the new capitalism", em Credit, Money And Macroeconomic Policy. A Post-Keynesian Approach, org. por Gnos, Claude e Rochon, Louis-Philippe, Cheltenham, Edward Elgar Publishing, pp. 13-32.

Berger, Allen N. e Bouwman, Christa H. S. (2009): "Bank Liquidity Creation", em The Review of Financial Studies, Vol. 22, n. ${ }^{\circ}$ 9, Setembro, pp. 3779-3837.

- (2013): "How does capital affect bank performance during financial crises?", em Journal of Financial Economics, Vol. 109, n. ${ }^{\circ}$ 1, Julho, pp. 146-176.

Bertay, Ata Can, Demirgüç-Kunt, Asli e Huizinga, Harry (2013): “Do we need big banks? Evidence on performance, strategy and market discipline", em Journal of Financial Intermediation, Vol. 22, n. ${ }^{\circ} 4$, Outubro, pp. 532-558.

Bologna, Pierluigi (2011): "Is there a role for funding in explaining recent US bank failures?”, Questioni di Economia e Finanza, Occasional Papers, n. ${ }^{\circ}$ 103, Outubro, Roma, Bank of Italy, 30 pp.

Bordo, Michael D., Mizrach, Bruce e Schwartz, Anna J. (1995): "Real versus Pseudo-International Systemic Risk: Lessons from History”, NBER Working Papers Series, n. ${ }^{\circ}$ 5371, Dezembro, Cambridge, Massachusetts, National Bureau of Economic Research, 45 pp.

Brunnermeier, Markus, Crocket, Andrew, Goodhart, Charles A. E., Persaud, Avinash D. e Shin, Hyun (2009): The Fundamental Principles of Financial Regulation, Genebra, International Center for Monetary and Banking Studies (ICMB).

Burson, Richard C. (2011): "The Dodd-Frank Act regulation of proprietary trading - the Volcker Rule", em Annual Review of Banking and Financial Law, Vol. 30, pp. 13-22. 
Calvão da Silva, João (2013): Titularização de Créditos - Securitization: No coração da crise financeira global, 3. ${ }^{\text {a }}$ ed., Coimbra, Almedina.

Campolongo, Francesca, Cariboni, Jessica, Guilleme Moreno, David e Uboldi, Adamo (2009): "Possible models for risk-based contributions to EU Deposit Guarantee Schemes”, JRC Scientific and Technical Reports, n. ${ }^{\circ}$ JRC 56320, Luxemburgo, European Commission, Joint Research Centre, Institute for the Protection and Security of the Citizen, 53 pp.

Campolongo, Francesca, Cariboni, Jessica e Uboldi, Adamo (2008): "Risk-based Contributions in EU Deposit Guarantee Schemes: Current Practices", JRC Scientific and Technical Reports, n. ${ }^{\circ} \mathrm{JRC}$ 48945, Luxemburgo, European Commission, Joint Research Centre, Institute for the Protection and Security of the Citizen, $62 \mathrm{pp}$.

Carpenter, David H. e Murphy, M. Maureen (2010a): "Permissible Securities Activities of Commercial Banks Under the Glass-Steagall Act (GSA) and the Gramm-Leach-Bliley Act (GLBA)", Congressional Research Service Report, n. ${ }^{\circ}$ R41181, 12 de Abril, Washington DC, Congressional Research Service (CRS).

— (2010b): "The "Volcker Rule": Proposals to Limit "Speculative" Proprietary Trading by Banks", Congressional Research Service Report, n. ${ }^{\circ}$ R41298, 22 de Junho, Washington DC, Congressional Research Service (CRS).

Comissão Europeia (2005): Livro verde - O crédito hipotecário na UE, Bruxelas, 19.07.2005, COM(2005) 327 final.

- (2010a): Comunicação da Comissão: Europa 2020 - Estratégia para um crescimento inteligente, sustentável e inclusivo, Bruxelas, 03.03.2010, COM(2012) 2020 final.

- (2010b): Proposta de Directiva .../.../UE do Parlamento Europeu e do Conselho relativa aos sistemas de garantia de depósitos [reformulação], Bruxelas, 12.07.2010, COM(2010) 368 final - 2010/0207 (COD).

- (2012a): Comunicação da Comissão ao Parlamento Europeu e ao Conselho: roteiro para uma união bancária, Bruxelas, 12.09.2012, COM(2012) 510 final.

- (2012b): "High-Level Expert Group on reforming the structure of the EU banking sector - mandate", Fevereiro, Bruxelas, Comissão Europeia, 1 pp. [formato electrónico disponível em http://ec.europa.eu/internal_market/bank/docs/ high-level_expert_group/mandate_en.pdf].

- (2012c): Proposta de Directiva do Parlamento Europen e do Conselho que estabelece um enquadramento para a recuperação e resolução de instituições de crédito e empresas de investimento e que altera as Diretivas 
77/91/CEE e 82/891/CE do Conselho, as Diretivas 2001/24/ CE, 2004/47/CE, 2004/25/CE, 2005/56/CE, 2007/36/CE e 2011/55/CE e o Regulamento (UE) n. ${ }^{\circ}$ 1093/2010, Bruxelas, 06.06.2012, COM(2012) 280 final - 2012/0150 (COD).

- (2013): Proposta de Regulamento do Parlamento Europeu e do Conselho que estabelece regras e um procedimento uniformes para a resolução de instituições de crédito e de certas empresas de investimento no quadro de um mecanismo único de resolução e de um fundo único de resolução bancária e que altera o Regulamento (UE) n. ${ }^{\circ} 1093 / 2010$ do Parlamento Europeu e do Conselho, Bruxelas, 10.7.2013, COM(2013) 520 final - 2013/0253 (COD).

Cooper, Elizabeth W. (2011): "Determinants of off-balance sheet usage in private banks", em Studies in Economics and Finance, Vol. 28, n. ${ }^{\circ}$ 4, Inverno, pp. 248-259.

Cornett, Marcia Millon, McNutt, Jamie John, Strahan, Philip E. e Tehranian, Hassan (2011): "Liquidity risk management and credit supply in the financial crisis", em Journal of Financial Economics, Vol 101, n. ${ }^{\circ}$ 2, Agosto, pp. 297-312.

Crockett, Andrew D. (2001): "Why is Financial Stability a Goal of Public Policy?", em Maintaining Financial Stability in a Global Economy: A Symposium Sponsored by The Federal Reserve Bank of Kansas City, reimp., org. por Federal Reserve Bank of Kansas City, Nova Iorque, Books for Business, pp. 7-36 (1. ${ }^{\mathrm{a}}$ ed., 1997).

Davis, E. Philip (2009): "Financial Stability in the United Kingdom: Banking on Prudence", OECD Economics Department Working Papers, Paris, OECD publishing, 27 pp.

Demirgüç-Kunt, Asli e Huizinga, Harry (2010): "Bank activity and funding strategies: The impact on risk and returns", em Journal of Financial Economics, Vol. 98, n. ${ }^{\circ}$ 3, Dezembro, pp. 626-650.

- (2013): "Are banks too big to fail or too big to save? International evidence from equity prices and CDS spreads", em Journal of Banking and Finance, Vol. 37, n. ${ }^{\circ}$ 3, Março, pp. 875-894.

EGGERT, Kurt (2009): “The great collapse: how securitization caused the subprime meltdown", em Connecticut Law Review, Vol. 41, n. ${ }^{\circ}$ 4, Maio, pp. 1257-1312

European Commission (2013): “A comprehensive EU response to the financial crisis: substantial progress towards a strong financial framework for Europe and a banking union for the eurozone", Press release, n. $^{\circ}$ MEMO/13/1168, 17 de Dezembro de 2013, Bruxelas, 9 pp. 
Feldstein, Martin (1991): "The Risk of Economic Crisis: Introduction”, em The Risk of Economic Crisis, org. por Feldstein, Martin, Chicago, The University of Chicago Press, pp. 1-18.

Fernando, Chitru S. e Herring, Richard J. (2001): "Liquidity Shocks, Systemic Risk, and Market Collapse: Theory and Application to the Market for Perps", Center for Financial Institutions Working Papers, n. ${ }^{\circ}$ 01-34, Agosto, Filadélfia, Wharton School Center for Financial Institutions, University of Pennsylvania, $41 \mathrm{pp}$.

Ferreira, Eduardo Paz (2012): “Artigo 119. ${ }^{\circ}$ do Tratado sobre o Funcionamento da União Europeia”, em Tratado de Lisboa Anotado e Comentado, org. por Porto, Manuel Lopes e AnAstácio, Gonçalo, Coimbra, Almedina, pp. 554-558.

Focarelli, Dario, Marques-Ibanez, David e Pozzolo, Alberto Franco (2011): “Are Universal Banks Better Underwriters? Evidence From the Last Days of the Glass-Steagall Act", ECB Working Paper, n. ${ }^{\circ}$ 1287, Janeiro, Frankfurt am Main, European Central Bank, 34 pp.

Friedman, Milton e Schwartz, Anna J. (1993): A Monetary History of the United States, 1867-1960, reimp., Princeton, Princeton University Press (1. ${ }^{a}$ ed., 1963).

Gomes, António Ferreira (2012): “Artigo 127. do Tratado sobre o Funcionamento da União Europeia”, em Tratado de Lisboa Anotado e Comentado, org. por Porto, Manuel Lopes e AnAstácio, Gonçalo, Coimbra, Almedina, pp. 582-585.

Goodhart, Charles A. E. e Wagner, Wolf (2012): "Regulators should encourage more diversity in the financial system", em VoxEU.org - Research-based policy analysis and commentary from leading economists, 12 de Abril [formato electrónico disponível em http://www.voxeu.org/article/ regulators-should-encourage-more-diversity-financial-system].

Hellwig, Martin (2008): "Systemic Risk in the Financial Sector: An Analysis of the Subprime-Mortgage Financial Crisis", Working Paper Series of the Max Planck Institute for Research on Collective Goods, n. ${ }^{\circ}$ 43, Novembro, Bona, Max Planck Institute for Research on Collective Goods, 73 pp.

Herring, Richard J. e Santomero, Anthony M. (2000): "What is Optimal Financial Regulation?”, em The New Financial Architecture: Banking Regulation in the 21st Century, org. por Gup, Benton E., Westport, Connecticut, Quorum Books, pp. 51-84.

JacoBs, Bruce I. (2009): “Tumbling Tower of Babel: Subprime Securitization and the Credit Crisis", em Financial Analysts Journal,Vol. 65, n. ${ }^{\circ}$ 2, Abril, pp. 17-30. 
Karim, Dilruba, Liadze, Iana, Barrell, Ray e Davis, E. Philip (2013): “Off-balance sheet exposures and banking crises in OECD countries", em Journal of Financial Stability,Vol. 9, n. ${ }^{\circ}$ 4, Dezembro, pp. 673-681.

Kaufman, George G. (1995): “Comment on Systemic Risk”, em Banking, Financial Markets, and Systemic Risk, org. por KaUfman, George G., Greenwich, Connecticut, JAI Press, pp. 47-52.

- (2000a): "Banking and Currency Crises and Systemic Risk: A Taxonomy and Review", DNB Staff Reports, n. ${ }^{\circ} 48$, Bank of the Netherlands, 84 pp.

- (2000b): "Banking and Currency Crises and Systemic Risk: Lessons from Recent Events", em Economic Perspectives - Federal Reserve Bank of Chicago, 3. ${ }^{\circ}$ Trimestre, pp. 9-28.

- (2000c): "How Real Is the Risk of a Massive Banking Collapse?”, em Regulation,Vol. 23, n. ${ }^{\circ}$ 1, Primavera, pp. 25-30.

- (2000d): "The Myth of Systemic Risk", em Financial Services Newsletter (The Federalist Society for Law and Public Policy Studies), Vol. 3, n. ${ }^{\circ}$ 3, pp. 1-4.

Keys, Benjamin J., Mukherjee, Tanmoy, Seru, Amit e Vig, Vikrant (2010): "Did Securitization Lead to Lax Screening? Evidence from Subprime Loans”, em The Quarterly Journal of Economics, Vol. 125, n. ${ }^{\circ}$ 1, Fevereiro, pp. 307-362.

Keys, Benjamin J., Seru, Amit e Vig, Vikrant (2012): “Lender Screening and the Role of Securitization: Evidence from Prime and Subprime Mortgage Markets", em The Review of Financial Studies, Vol. 25, n. ${ }^{\circ}$ 7, pp. 2071-2108.

Kregel, Jan A. (2010a): “Can a Return to Glass-Steagall Provide Financial Stability in the US Financial System?”, em PSL Quarterly Review, Vol. 63, n. ${ }^{\circ} 252$, pp. 37-73.

- (2010b): "No Going Back: Why We Can Not Restore Glass-Steagall's Segregation of Banking and Finance", Public Policy Brief, n. 107 , Annandale-on-Hudson, Nova Iorque, Levy Economics Institute of Bard College, 17 pp.

- (2011): "Will restricting proprietary trading and stricter derivatives regulation make the US financial system more stable?", em PSL Quarterly Review,Vol. 64, n. ${ }^{\circ}$ 258, pp. 227-247.

Limkanen, Erkki [Presidente], Bänziger, Hugo, Campa, José Manuel, Gallois, Louis, Goyens, Monique, Krahnen, Jan Pieter, MazzucChelli, Marco, Sergeant, Carol, Tuma, Zdenek, Vanhevel, Jan e WijfFels, Herman (2012): High-level Expert Group on reforming the structure of the EU banking sector - final report, Bruxelas, 2 de Outubro de 2012 [formato electrónico disponível em http://ec.europa. 
eu/internal_market/bank/docs/high-level_expert_group/ liikanen-report/final_report_en.pdf].

MAYer, Martin (2011): "Glass-Steagall in Our Future: How Straight, How Narrow", em Financial Market Regulation: Legislation and Implications, org. por TAтом, John A., Nova Iorque, Springer, pp. 31-41.

Merkley, Jeff e Levin, Carl (2011): “The Dodd-Frank Act restrictions on proprietary trading and conflicts of interest: new tools to address evolving threats", em Harvard Journal on Legislation, Vol. 48, n. ${ }^{\circ}$, Verão, pp. 515-553.

Morrison, Alan (2009): "Universal Banking", em Oxford Handbook of Banking, org. por Berger, Allen, Molyneux, Philip e Wilson, John, Oxford, Oxford University Press, pp. 171-194.

Nadauld, Taylor D. e Sherlund, Shane M. (2013): "The impact of securitization on the expansion of subprime credit", em Journal of Financial Economics, Vol. 107, n. ${ }^{\circ}$ 2, pp. 454-476.

Pacces, Alessio Maria (2010): “Consequences of Uncertainty for Regulation: Law and Economics of the Financial Crisis", em European Company and Financial Law Review, Vol. 7, n. ${ }^{\circ}$ 4, Dezembro, pp. 479-511.

Peicuti, Cristina (2013): "Securitization and the subprime mortgage crisis", em Journal of Post Keynesian Economics, Vol. 35, n. ${ }^{\circ}$ 3, Abril, pp. 443-456.

Petersen, M. A., Mukuddem-Petersen, J., De Waal, B., Senosi, M. C. e Thomas, S. (2011): "Profit and Risk under Subprime Mortgage Securitization”, em Discrete Dynamics in Nature E Society, Vol. 2011, Special section, pp. 1-64.

Porto, Manuel Lopes (2012): "Artigo 26. ${ }^{\circ}$ do Tratado sobre o Funcionamento da União Europeia”, em Tratado de Lisboa Anotado e Comentado, org. por Porto, Manuel Lopes e AnAstácio, Gonçalo, Coimbra, Almedina, pp. 269-271.

Quelhas, José Manuel (1996): Sobre a evolução recente do sistema financeiro (Novos "produtos financeiros»), Coimbra, Separata do Boletim de Ciências Económicas da Faculdade de Direito da Universidade de Coimbra, distribuição da Livraria Almedina.

- (2012a): "Dos objectivos da União Bancária", em Boletim de Ciências Económicas, Vol. LV, 2012, pp. 235-298.

- (2012b): "Sobre a criação do Comité Europeu de Risco Sistémico", em Estudos em Homenagem ao Prof. Doutor Aníbal Almeida, org. por Avelãs Nunes, António José, Cunha, Luís Pedro e Martins, Maria Inês de Oliveira, Coimbra, Boletim da Faculdade de Direito, Studia Iuridica, 107, Ad Honorem, 7, Coimbra Editora, pp. 877-899. 
- (2012c): Sobre as crises financeiras, o risco sistémico e a incerteza sistemática, Coimbra, Almedina.

- (2013): "Quem é que a austeridade cura? Quem é que a austeridade mata? - Releitura dos memoranda entre a troika e os PIGS", em $A$ austeridade cura? A austeridade mata?, org. por FerreirA, Eduardo Paz, Lisboa, Lisboa Law Scholl Editions, AAFDL, pp. 845-868.

Schwartz, Anna J. (1995): "Systemic Risk and the Macroeconomy", em Banking, Financial Markets, and Systemic Risk, org. por Kaufman, George G., Greenwich, Connecticut, JAI Press, pp. 19-30.

— (1998): "Coping with Financial Fragility: A Global Perspective", em Coping with Financial Fragility and Systemic Risk, reimp., org. por BENINK, Harald A., Dordrecht, Kluwer Academic Publishers, pp. 251257 (1. ${ }^{a}$ ed., 1995).

SHIN, Hyun Song (2009a): "Reflections on Northern Rock: The bank run that heralded the global financial crisis", em Journal of Economic Perspectives, Vol. 23, n. ${ }^{\circ}$ 1, Inverno, pp. 101-119.

- (2009b): "Securitisation and Financial Stability (Report)", em The Economic Journal,Vol. 119, n..$^{\circ}$ 536, Março, pp. 309-332.

SimseK, Alp (2013): "Speculation and Risk Sharing with New Financial Assets", em The Quarterly Journal of Economics, Vol. 128, n. ${ }^{\circ} 3$, Agosto, pp. 1365-1396.

SingH, Manmohan (2010): "Collateral, Netting and Systemic Risk in the OTC Derivatives Market", IMF Working Paper, n. ${ }^{\circ}$ 10/99, Abril, Washington, International Monetary Fund, $15 \mathrm{pp}$.

SousA, Marcelo Rebelo de (2012): "Artigo 3..$^{\circ}$ do Tratado da União Europeia", em Tratado de Lisboa Anotado e Comentado, org. por PORTO, Manuel Lopes e AnAstácio, Gonçalo, Coimbra, Almedina, pp. 30-32.

Wilmarth Jr., Arthur E. (2009): "The Dark Side of Universal Banking: Financial Conglomerates and the Origins of the Subprime Financial Crisis", em Connecticut Law Review, Vol. 41, n. ${ }^{\circ}$ 4, Maio, pp. 963-1050.

Zaman, M. Raquibuz (2009): "The Causes and Ramifications of the 2008-2009 Meltdown of the Financial Markets on the Global Economy", em Eurasian Journal of Business and Economics, Vol. 2, n. ${ }^{\circ}$ 4, Novembro, pp. 63-76. 
Resumo: O artigo confronta os objectivos da carta de mandato da Comissão Europeia ao «Grupo de especialistas de alto nível sobre a reforma estrutural do sector bancário da União Europeia», de Fevereiro de 2012, com os resultados apresentados pelo "Grupo», no Relatório Final de Outubro de 2012, no qual se diagnosticam os factores deflagradores da crise do sector bancário.

Ao mesmo tempo, o artigo examina as propostas relativas à criação da União Bancária, dando particular enfase ao Mecanismo Único de Supervisão (MUS), ao Sistema Comum de Garantia de Depósitos (SGD) e ao Mecanismo Único de Resolução (MUR).

Por último, reflecte-se sobre a evolução do princípio de «banca universal», à luz do movimento pendular de regulação, desregulação e (re)regulação dos mercados financeiros.

Palavras-chave: Crise financeira de 2007; Instrumentos financeiros complexos; União bancária; Mecanismo único de supervisão (MUS); Mecanismo único de resolução (MUR); Sistema comum de garantia de depósitos (SGD); Redução do risco sistémico; Redução do risco de contágio; Redução do risco moral; Promoção da concorrência; Integridade do mercado interno.

Notes on the reform of the EU banking sector in the aftermath of the 2007 financial crisis

Abstract: In this article the objectives of the European Commission's February 2012 mandate letter to the "High-level Expert Group on reforming the structure of the EU banking sector» are checked against the results presented by the "Group» in its October 2012 Final Report, in which the banking crisis triggering factors are diagnosed.

The article also examines the proposals relating to the Banking Union creation, giving particular emphasis to the Single Supervisory Mechanism (SSM), the Common Deposit Guarantee Scheme (DGS) and the Single Resolution Mechanism (SRM).

Finally, we reflect on the evolution of the «universal banking» principle in the light of the pendulum movement between regulation, deregulation and (re)regulation in financial markets. 
Keywords: 2007 financial crisis; complex financial instruments; Banking Union; Single Supervisory Mechanism (SSM); Single Resolution Mechanism (SRM); Common Deposit Guarantee Scheme (DGS); systemic risk reduction; contagion risk reduction; moral hazard reduction; competition promotion; single market integrity.

José Manuel Quelhas

Faculdade de Direito da Universidade de Coimbra 